US Army Corps of Engineers

Prepared for the U.S. Army Corps of Engineers, Portland District, under a Government Order with the U.S. Department of Energy

Contract DE-AC05-76RL01830

\title{
Monitoring of Juvenile Subyearling Chinook Salmon Survival and Passage at John Day Dam, Summer 2010
}

\section{Summary Report}

Pacific Northwest National Laboratory

University of Washington

Pacific States Marine Fisheries Commission

November 2012

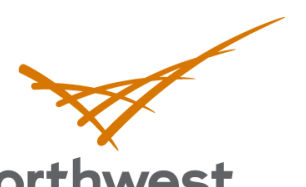

Pacific Northwest

NATIONAL LABORATORY

Proudly Operated by Battelle Since 1965 


\title{
DISCLAIMER
}

This report was prepared as an account of work sponsored by an agency of the United States Government. Neither the United States Government nor any agency thereof, nor Battelle Memorial Institute, nor any of their employees, makes any warranty, express or implied, or assumes any legal liability or responsibility for the accuracy, completeness, or usefulness of any information, apparatus, product, or process disclosed, or represents that its use would not infringe privately owned rights. Reference herein to any specific commercial product, process, or service by trade name, trademark, manufacturer, or otherwise does not necessarily constitute or imply its endorsement, recommendation, or favoring by the United States Government or any agency thereof, or Battelle Memorial Institute. The views and opinions of authors expressed herein do not necessarily state or reflect those of the United States Government or any agency thereof.

\author{
PACIFIC NORTHWEST NATIONAL LABORATORY \\ operated by \\ BATTELLE \\ for the \\ UNITED STATES DEPARTMENT OF ENERGY \\ under Contract DE-AC05-76RL01830
}

\author{
Printed in the United States of America \\ Available to DOE and DOE contractors from the \\ Office of Scientific and Technical Information, \\ P.O. Box 62, Oak Ridge, TN 37831-0062; \\ ph: $(865) 576-8401$ \\ fax: $(865) 576-5728$ \\ email: reports@adonis.osti.gov
}
Available to the public from the National Technical Information Service
$\mathbf{5 3 0 1}$ Shawnee Rd., Alexandria, VA 22312
ph: (800) 553-NTIS (6847)
email: orders@ntis.gov $<$ http://www.ntis.gov/about/form.aspx $>$
Online ordering: http://www.ntis.gov

This document was printed on recycled paper. 


\section{Monitoring of Juvenile Subyearling Chinook Salmon Survival and Passage at John Day Dam, Summer 2010}

\section{Summary Report}

$\begin{array}{ll}\text { MA Weiland } & \text { Z Deng } \\ \text { GR Ploskey } & \text { TJ Carlson } \\ \text { JS Hughes } & \text { JR Skalski } \\ \text { CM Woodley } & \text { RL Townsend }\end{array}$

November 2012

Prepared for:

U.S. Army Corps of Engineers, Portland District

under a Government Order with the U.S. Department of Energy

Contract DE-AC05-76RL01830

Prepared by:

Pacific Northwest National Laboratory

P.O. Box 999

Richland, Washington 99352 


\section{Preface}

This study was conducted by the Pacific Northwest National Laboratory (PNNL), the Pacific States Marine Fisheries Commission, and the University of Washington (UW) for the U.S. Army Corps of Engineers, Portland District (USACE). The PNNL and UW project managers are Drs. Thomas J. Carlson and John R. Skalski, respectively. The USACE technical lead is Mr. Brad Eppard. The study was designed using a single-release model to estimate rates of survival and passage of juvenile salmonids passing John Day Dam at two spill treatment levels, $30 \%$ and $40 \%$ of total project discharge, and to provide additional performance measures as stipulated in the Columbia Basin Fish Accords for subyearling Chinook salmon (Oncorhynchus tshawytscha). The study was not intended to formally evaluate survival rates relative to performance standards set forth in the 2008 Federal Columbia River Power System Biological Opinion, because long-term juvenile salmonid protection measures at John Day Dam had yet to be finalized at the time of the study.

This report focuses on summer out-migrating subyearling Chinook salmon. A separate monitoring report will present the findings of the survival studies of yearling Chinook salmon and juvenile steelhead (O. mykiss) at John Day Dam during 2010. A comprehensive technical report of the spring and summer 2010 tagging studies at John Day Dam, including behavioral and fish passage results, for yearling and subyearling Chinook salmon, and steelhead will be presented in a separate report. 


\section{Executive Summary}

The purpose of the study reported herein was to evaluate dam passage survival of subyearling Chinook salmon (Oncorhynchus tshawytscha; CH0) at John Day Dam (JDA) during summer 2010. The study was conducted by researchers from the Pacific Northwest National Laboratory (PNNL) in collaboration with the Pacific States Marine Fisheries Commission (PSMFC) and the University of Washington (UW). It was designed to estimate the effects of $30 \%$ and $40 \%$ spill treatment levels on single-release survival rates of $\mathrm{CH} 0$ passing through two reaches: 1) the dam and $40 \mathrm{~km}$ of tailwater, and 2) the forebay, dam, and $40 \mathrm{~km}$ of tailwater. The study also estimated additional passage performance measures, which are stipulated in the Columbia Basin Fish Accords.

This study was not an official compliance test as described by the 2008 Federal Columbia River Power System (FCRPS) Biological Opinion (BiOp, NOAA 2008), because passage conditions for the dam had not yet been finalized. Changes in 2010 at JDA to improve fish passage and survival rates included relocating the top-spill weirs (TSWs) from spill bays 15 and 16 to spill bays 18 and 19, modifying the deflector at spill bay 20 , and installing avian wires in the tailrace.

Juvenile Salmon Acoustic Telemetry System (JSATS) cabled arrays were monitored at JDA until August 5 for detection of $2660 \mathrm{CH} 0$ tagged with JSATS micro-transmitters. The last CH0 at JDA used in the survival analysis was detected at the dam on July 20. Two spill treatments were tested at JDA in summer 2010 between June 13 and July 19-30\% and 40\% spill out of total project discharge. Passage survival rates at JDA is estimated from the upstream face of JDA at river kilometer (rkm) 349 (Columbia River 349 [CR349]) to the cabled array at the upstream face of The Dalles Dam (TDA, CR309), $40 \mathrm{rkm}$ downstream. Under the 2008 FCRPS BiOp, the dam passage survival rate for $\mathrm{CH} 0$ should be greater than or equal to $93 \%$ and estimated with a standard error (SE) less than or equal to $1.5 \%$. Also estimated were forebay residence time, tailrace egress time, and spill passage efficiency (SPE), as required in the Columbia Basin Fish Accords. However, this study was not an official BiOp compliance test because the long-term passage measures at JDA had yet to be finalized at the time of this study, and the study design was based on a single-release survival model instead of the virtual paired reference release model.

A virtual/single-release model was used to estimate dam-and-tailwater-passage and forebay-dam-andtailwater-passage survival rates for fish passing through JDA. The approach included releases of CH0, tagged with JSATS acoustic micro-transmitters, $41 \mathrm{rkm}$ above JDA that contributed to the formation of a virtual release if released fish were detected on the forebay entrance array or at the face of the dam. All survival rates are single-release estimates. A total of $2849 \mathrm{CH} 0$ were tagged and released into the river near Roosevelt, Washington (CR390). Survival rates were estimated from the detection array in the forebay and on the upstream face of JDA through Lake Celilo to the detection array on the upstream face of TDA. The JSATS micro-transmitter, tag model number ATS-156 dB, weighing $0.438 \mathrm{~g}$ in air, was used in this investigation.

The study methods and environmental and operational conditions are summarized in Tables ES.1. Study results for survival and performance metrics are summarized in Table ES.2. 
Table ES.1. Summary of Methods and Conditions at John Day Dam, Summer 2010

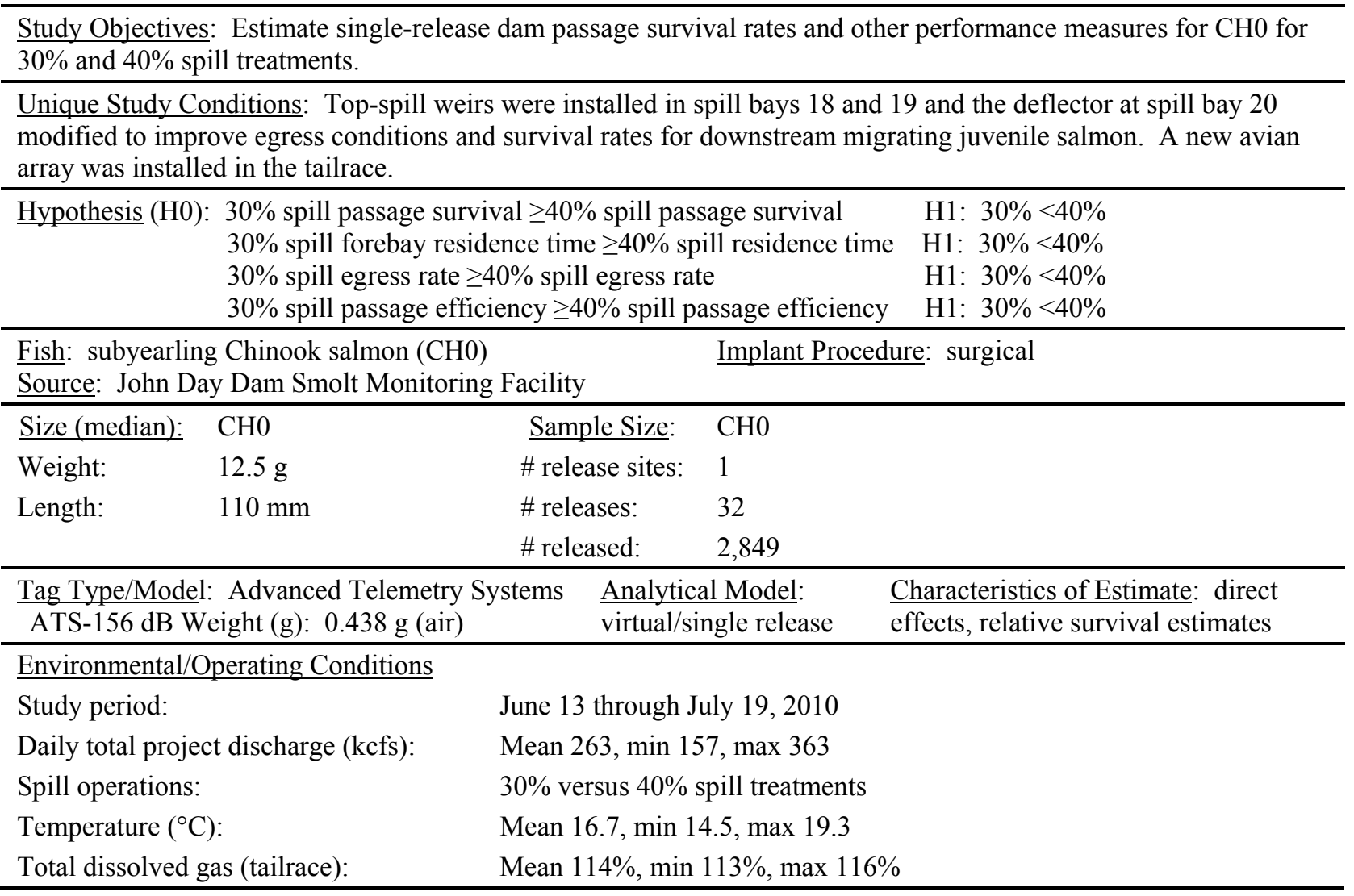

Table ES.2. Summary of Survival Rates and Other Performance Metrics at John Day Dam, Summer 2010. Travel time median and means (respectively) are provided in hours.

\begin{tabular}{lccc}
\hline \multicolumn{1}{c}{ Metric } & Combined Spill & $30 \%$ Spill & $40 \%$ Spill \\
\hline Survival: dam passage to TDA & $0.908(\widehat{\mathrm{SE}}=0.006)$ & $0.919(\widehat{\mathrm{SE}}=0.008)$ & $0.914(\widehat{\mathrm{SE}}=0.008)$ \\
Survival: forebay entrance array to & $0.904(\widehat{\mathrm{SE}}=0.006)$ & $0.915(\widehat{\mathrm{SE}}=0.008)$ & $0.907(\widehat{\mathrm{SE}}=0.008)$ \\
TDA & $1.83 ; 3.83$ & $1.95 ; 4.00$ & $1.76 ; 3.67$ \\
Forebay Residence Time & $0.29 ; 2.06$ & $0.36 ; 2.30$ & $0.26 ; 1.83$ \\
100-m Forebay Residence Time & $0.62 ; 1.94$ & $0.57 ; 1.60$ & $0.56 ; 2.18$ \\
Tailrace Egress Time & $0.883(\widehat{\mathrm{SE}}=0.006)$ & $0.857(\widehat{\mathrm{SE}}=0.010)$ & $0.908(\widehat{\mathrm{SE}}=0.008)$ \\
Fish Passage Efficiency & $0.776(\widehat{\mathrm{SE}}=0.008)$ & $0.741(\widehat{\mathrm{SE}}=0.012)$ & $0.810(\widehat{\mathrm{SE}}=0.011)$ \\
Spill Passage Efficiency & & & \\
\hline
\end{tabular}




\section{Acknowledgments}

Many people from the Pacific Northwest National Laboratory (PNNL), the Pacific States Marine

Fisheries Commission (PSMFC), the U.S. Army Corps of Engineers, Portland District (USACE), and the University of Washington (UW) made valuable contributions to this study and deserve acknowledgment.

- PNNL: C Arimescu, G Batten, B Bellgraph, R Brown, S Carpenter, J Carter, K Carter, E Choi, K Deters, G Dirkes, J Duncan, S Ennor, D Faber, E Fischer, T Fu G Gaulke, M Gay, D Geist, K Hall, K Ham, R Harnish, M Hennen, M Hughes, F Khan, J Kim, K Knox, B Lamarche, K Lavender, J Martinez, G McMichael, K Neiderhiser, B Noland, E Oldenburg, I Royer, S Schlahta, N Tavan, S Titzler, N Trimble, and S Zimmerman.

- PSMFC: R Martinson, P Kahut, G Kolvachuk, C Anderson, C Cushing, D Etherington, G George, S Goss, T Monter, T Mitchell, R Plante, M Walker, R Wall, and M Wilberding.

- USACE: B Eppard, M Langeslay, B Cordie, D Schwartz, M Zyndol, and electricians, operators, and biologists at Bonneville, John Day, and The Dalles dams.

- UW: J Lady, A Seaburg, and P Westhagen.

We also wish to acknowledge the manufacturers of the tags, hydrophones, and hardware required to accomplish testing.

- Advanced Telemetry Systems (ATS), Inc. manufactured the JSATS acoustic tags.

- Autonomous and dam-mounted hydrophones were produced by Sonic Concepts, Seattle, Washington.

- Precision Acoustic Systems, Seattle, Washington, manufactured the quad channel receivers and conducted node acceptance tests for PNNL.

- Cascade Aquatics, Inc., Ellensburg, Washington, activated and delivered the acoustic tags.

- The Dalles Ironworks, The Dalles, Oregon, fabricated anchors for autonomous nodes and frames for star clusters that were deployed in the spillway forebay. 


\section{Acronyms and Abbreviations}

\begin{tabular}{|c|c|}
\hline${ }^{\circ} \mathrm{C}$ & degree(s) Celsius \\
\hline $2 \mathrm{D}$ & two-dimensional \\
\hline $3 \mathrm{D}$ & three dimensional \\
\hline $\mathrm{BiOp}$ & Biological Opinion \\
\hline $\mathrm{BON}$ & Bonneville Dam \\
\hline BRZ & boat-restricted zone \\
\hline $\mathrm{CHO}$ & subyearling Chinook salmon \\
\hline CR234 & Bonneville Dam dam-face array; John Day Dam tertiary survival-detection array \\
\hline CR275 & $\begin{array}{l}\text { Hood River, Oregon autonomous node array; John Day Dam secondary survival- } \\
\text { detection array }\end{array}$ \\
\hline CR309 & The Dalles Dam dam-face array; John Day Dam primary survival-detection array \\
\hline CR346 & John Day Dam tailwater-egress array \\
\hline CR349 & John Day Dam dam-face array \\
\hline CR351 & John Day Dam forebay entrance array \\
\hline CR390 & Roosevelt, Washington release location $\left(\mathrm{R}_{1}\right)$ \\
\hline d & $\operatorname{day}(\mathrm{s})$ \\
\hline FCRPS & Federal Columbia River Power System \\
\hline FPE & fish passage efficiency \\
\hline $\mathrm{ft}$ & foot/feet \\
\hline g & $\operatorname{gram}(\mathrm{s})$ \\
\hline $\mathrm{h}$ & hour(s) \\
\hline HA & hydroacoustic \\
\hline JBS & juvenile bypass system \\
\hline JDA & John Day Dam \\
\hline JSATS & Juvenile Salmon Acoustic Telemetry System \\
\hline $\mathrm{kcfs}$ & thousand cubic feet per second \\
\hline $\mathrm{km}$ & kilometer(s) \\
\hline $\mathrm{L}$ & liter(s) \\
\hline $\mathrm{m}$ & meter(s) \\
\hline $\mathrm{mg}$ & milligram(s) \\
\hline $\mathrm{mm}$ & millimeter(s) \\
\hline MOA & Memorandum of Agreement \\
\hline MS-222 & tricaine methanesulfonate \\
\hline PIT & passive integrated transponder \\
\hline PNNL & Pacific Northwest National Laboratory \\
\hline PRI & pulse repetition interval \\
\hline
\end{tabular}




$\begin{array}{ll}\text { PSMFC } & \begin{array}{l}\text { Pacific States Marine Fisheries Commission } \\ \text { river kilometer(s) } \\ \text { RME }\end{array} \\ \text { research, monitoring, and evaluation } \\ \text { ROR } & \text { run-of-river } \\ \text { RPA } & \text { Reasonable and Prudent Alternative } \\ \text { RT } & \text { radio telemetry } \\ \text { S } & \text { second(s) } \\ \text { SE } & \text { standard error } \\ \text { SPE } & \text { spill passage efficiency } \\ \text { TDA } & \text { The Dalles Dam } \\ \text { TSW } & \text { top-spill weir } \\ \text { USACE } & \text { U.S. Army Corps of Engineers } \\ \text { UW } & \text { University of Washington }\end{array}$




\section{Contents}

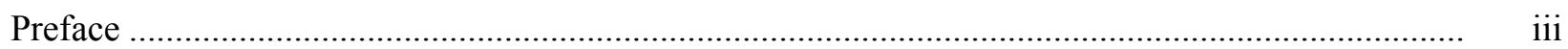

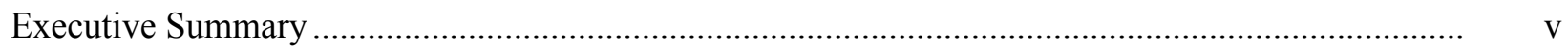

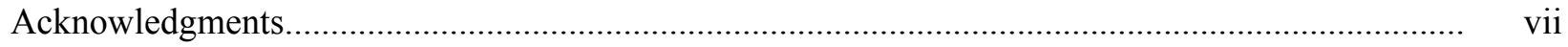

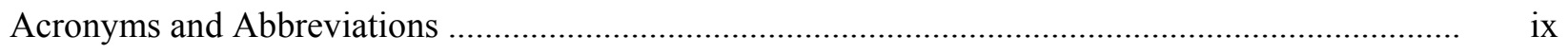

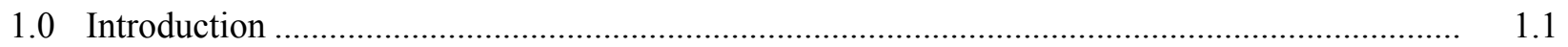

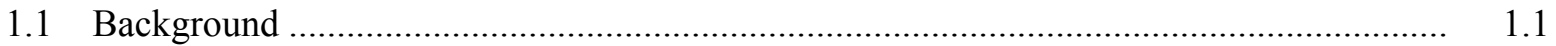

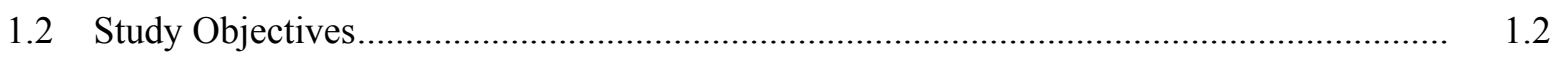

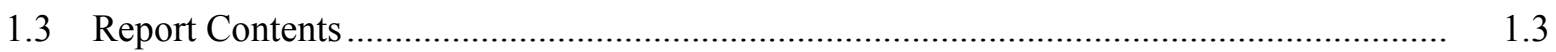

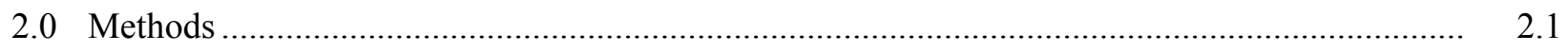

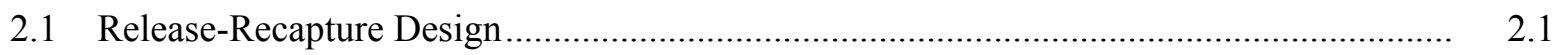

2.1.1 Spill Treatments...................................................................................... 2.2

2.2 Handling, Tagging, and Release Procedures ............................................................... 2.3

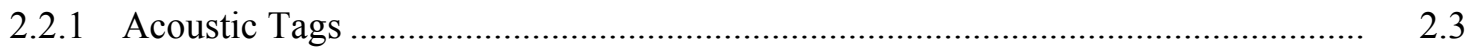

2.2.2 Fish Collection ...................................................................................... 2.3

2.2.3 Tagging Procedure ..................................................................................... 2.4

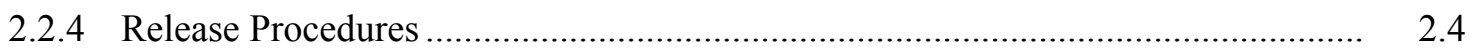

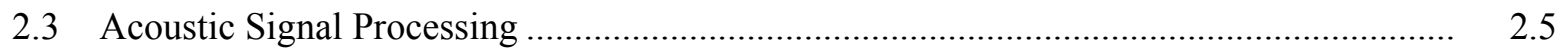

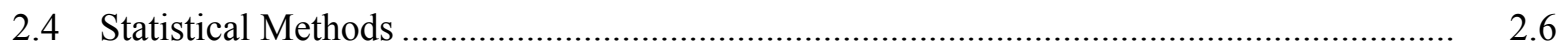

2.4.1 Estimation of Dam Passage Survival Rates ....................................................... 2.6

2.4.2 Tag-Life Analysis ................................................................................... 2.6

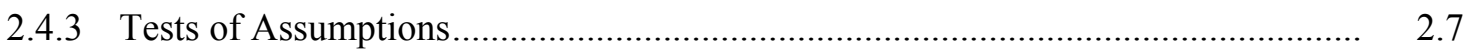

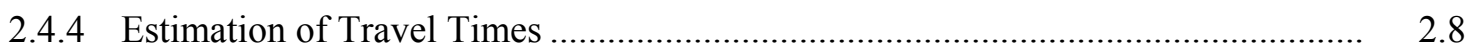

2.4.5 Estimation of Spill Passage Efficiency ............................................................. 2.9

2.4.6 Estimation of Fish Passage Efficiency ............................................................ 2.9

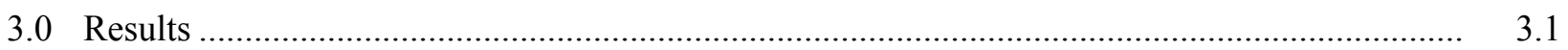

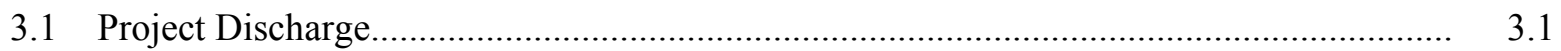

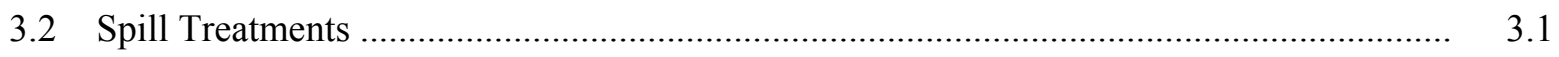

3.3 Assessment of Assumptions .................................................................................. 3.2

3.3.1 Fish Size Distribution ........................................................................... 3.2

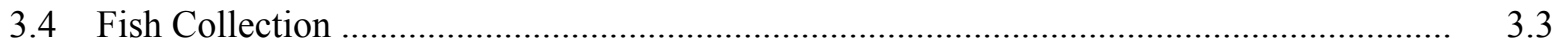

3.5 Handling Mortality and Tag Shedding .................................................................. 3.4

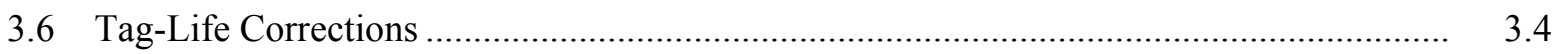

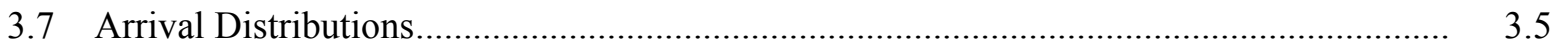

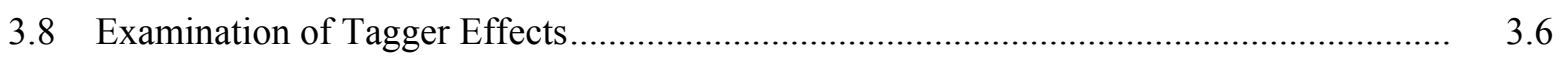

3.9 Survival and Passage Estimates.......................................................................... 3.7

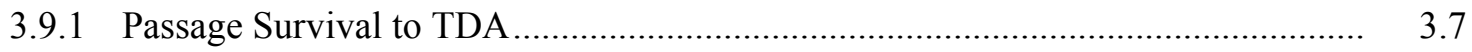

3.9.2 Spill Treatment Effects on Survival Rate ....................................................... 3.8 


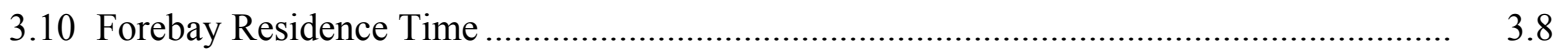

3.11 100-m Forebay Residence Time .......................................................................... $\quad 3.9$

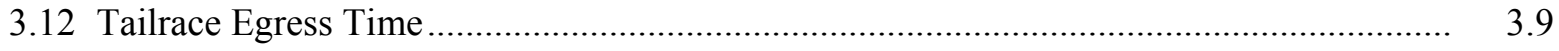

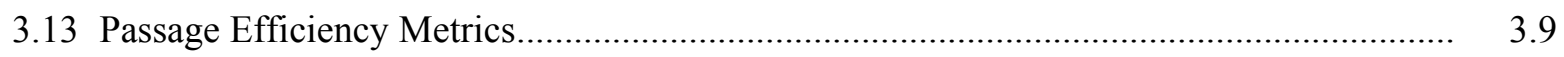

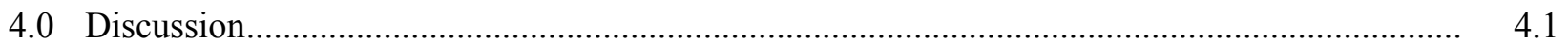

4.1 Reasonableness of Model Assumptions ..................................................................... 4.1

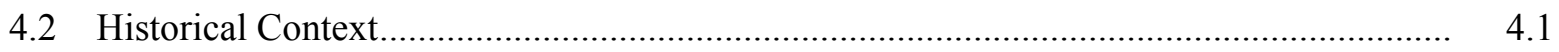

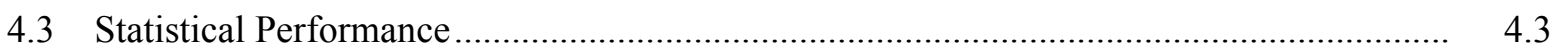

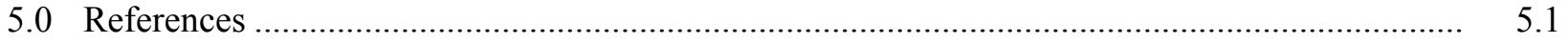

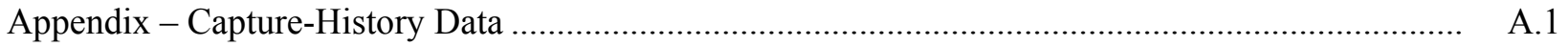

\section{Figures}

2.1 Schematic of the Single-Release Model Design Used to Estimate Dam Passage Survival from the John Day Dam Forebay and Dam-Face to The Dalles Dam ...................................... 2.1

2.2 Spill Treatment Schedule for the Summer Season at JDA.................................................. 2.2

3.1 Average Daily Water Discharge from JDA During the Summer 2010 Study and for the Preceding 10-Year Period .............................................................................................

3.2 Spill Treatments for the Summer Study at JDA, June 13 Through July 19, 2010 .................. 3.2

3.3 Relative Frequency Distributions for Fish Length of CH0 Sampled at JDA, Summer 2010.

3.4 Individual Failure Times for the $n=50$ Acoustic Tags Used in the Tag-Life Study, Along with the Fitted Four-Parameter Vitality Model of Li and Anderson (2009).

3.5 Plot of the Fitted Tag-Life Survivorship Curve and the Cumulative Arrival-Time Distributions of CH0 at the JDA Dam-Face Array(CR349), TDA Dam-Face Array (CR309), the Hood River Autonomous Node Array (CR275), and the BON Dam-Face Array (CR234)

\section{Tables}

ES.1 Summary of Methods and Conditions at John Day Dam, Summer 2010

ES.2 Summary of Survival Rates and Other Performance Metrics at John Day Dam, Summer 2010.

2.1 Sample Sizes of CH0 Tagged with Acoustic Micro-Transmitters Released Above JDA near Roosevelt, Washington (CR390) in Summer 2010 and Regrouped as a Virtual Release at the Dam Face to Estimate Dam Passage Survival

2.2 Release Times for the Fish Tagged with Acoustic Micro-Transmitters near Roosevelt, Washington 
3.1 Summary of the Number and Percent of Fish Rejected, Excluded, Tagged and Released Alive, Tagged and Released Dead, and that Exceeded Collection Needs

3.2 Rejection Numbers and Percentages due to Fish Maladies

3.3 Exclusion Numbers and Percentages Due to Failure to Meet Study Criteria

3.4 Number of CH0 Tagged for Release at $\mathrm{R}_{1}$ by Tagger.

3.5 Cormack-Jolly-Seber Estimates of Reach Survival Rates by Tagger for Subyearling Chinook Salmon.

3.6 Estimates of Survival Rates for $\mathrm{CH} 0$ Passing JDA Through Various Routes and Traveling to the Upstream Face of TDA in Summer 2010 .

3.7 Estimates of Survival Rates for CH0 Passing JDA through Various Routes and Traveling to the Upstream Face of TDA (CR309) During 30\% and 40\% Spill Treatments in Summer 2010

3.8 Median and Mean Estimated Forebay Residence Time for CH0 at JDA in 2010

3.9 Median and Mean Estimated 100-m Residence Time for CH0 at JDA in 2010

3.10 Estimated Median and Mean Tailrace Egress Time for CH0 at JDA in 2010

3.11 Summary of Other Performance Metrics at John Day Dam, Summer 2010

4.1 Single-Release Survival Estimates of CH0 at JDA from 2008 to 2010

4.2 Estimates of Spill Passage Efficiency and Fish Passage Efficiency for CH0 from Current and Previous Radio Telemetry, Acoustic Telemetry, and Hydroacoustic Studies at JDA from 2002 to 2010 


\subsection{Introduction}

Researchers at the Pacific Northwest National Laboratory (PNNL), the Pacific States Marine Fisheries Commission (PSMFC), and the University of Washington (UW) conducted a juvenile fish passage and survival study for the U.S. Army Corps of Engineers, Portland District (USACE). The study reported herein was primarily designed to estimate the survival rates of subyearling Chinook salmon (Oncorhynchus tshawytscha; CH0) passing through John Day Dam (JDA) by the various routes and through $40 \mathrm{~km}$ of tailwater using a single-release survival model. Additional passage performance measures were estimated, most of which were stipulated in the Columbia Basin Fish Accords.

The 2010 study was not an official compliance test as described by the 2008 Federal Columbia River Power System (FCRPS) Biological Opinion (BiOp; NOAA 2008), because passage conditions for the dam had not been finalized. The primary goal of the current study was to estimate the survival rates of $\mathrm{CH} 0$ passing through the dam by various routes and $40 \mathrm{~km}$ of tailwater using a single-release survival model. The effects of two spillway discharge treatments (30\% and $40 \%$ spill) and the performance of the top-spill weirs (TSWs) on survival and passage performance measures were also evaluated. The USACE and regional fisheries managers will use the data to adaptively manage the configuration and operation of JDA to maximize the survival rate of juvenile salmonids.

\subsection{Background}

The FCRPS 2008 BiOp contains Reasonable and Prudent Alternatives (RPAs) that include actions calling for measurements of juvenile salmonid survival (RPAs 52.1 and 58.1). These RPAs are being addressed as part of the federal research, monitoring, and evaluation (RME) effort for the FCRPS BiOp. Most importantly, the FCRPS BiOp includes performance standards for juvenile salmonid survival in the FCRPS against which the Action Agencies (Bonneville Power Administration, Bureau of Reclamation, and USACE) must compare their estimates, as follows (after the RME Strategy 2 of the RPA):

Juvenile Dam Passage Performance Standards - The Action Agencies' juvenile performance standards are an average across Snake River and lower Columbia River dams of $96 \%$ average dam passage survival for spring Chinook and steelhead and 93\% average across all dams for Snake River subyearling Chinook. Dam passage survival is defined as survival from the upstream face of the dam to a standardized reference point in the tailrace.

The Memorandum of Agreement (MOA) between the three lower river tribes and the Action Agencies (known informally as the Fish Accords), contains three additional requirements relevant to the 2010 survival studies:

Dam Survival Performance Standard - Meet the 96\% dam passage survival standard for yearling Chinook and steelhead and the $93 \%$ standard for subyearling Chinook. Achievement of the standard is based on 2 years of empirical survival data....

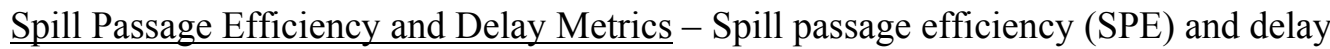
metrics under current spill conditions ... are not expected to be degraded ("no backsliding") with installation of new fish passage facilities at the dams.... 
Future Research, Monitoring, and Evaluation - The Action Agencies' dam survival studies for purposes of determining juvenile dam passage performance will also collect information about SPE, survival and delay between boat-restricted zones (BRZs), as well as other distribution and survival information. SPE and delay metrics will be considered in the performance check-ins or with Configuration and Operations Plan updates, but not as principal or priority metrics over dam survival performance standards. Once a dam meets the survival performance standard, SPE and delay metrics may be monitored coincidentally with dam survival testing.

This report summarizes the results of the 2010 summer acoustic telemetry study of CH0 at JDA. Only single-release survival estimates were calculated because there were no paired reference releases of fish downstream of JDA in 2010. Therefore, BiOp performance standards were not explicitly tested.

\subsection{Study Objectives}

The purpose of the summer 2010 spill treatment study at JDA was to estimate performance measures outlined in the 2008 FCRPS BiOp and the Fish Accords for CH0 using a single-release passage and survival model under $30 \%$ and $40 \%$ spill-discharge treatments, and evaluate the performance of the TSWs at spill bays 18 and 19. The following metrics were estimated using the Juvenile Salmon Acoustic Telemetry System (JSATS) technology for CH0:

- Dam passage survival, defined as the rate of survival from the upstream face of JDA (CR349) to the acoustic array at The Dalles Dam (TDA, CR309). Performance ${ }^{1}$ should be $\geq 93 \%$ survival rate for $\mathrm{CH} 0$. Survival rates were estimated with a standard error $(\mathrm{SE}) \leq 1.5 \%$. A single-release point estimate $\geq 93 \%$ also would exceed the BiOp standard for a paired-release estimate, because the singlerelease estimate is more conservative than the paired-release estimate.

- Survival rate from the forebay entrance array to the primary array $40 \mathrm{~km}$ downstream of the dam was estimated instead of forebay-to-tailrace survival rate, which was specified as BRZ-to-BRZ survival in the Fish Accords. Forebay to tailrace survival rate estimates require tailrace and tailwater reference releases that were not part of the 2010 study.

- SPE, defined as the fraction of the total number of fish going through the dam via the spillway.

- Fish passage efficiency (FPE), defined as the fraction of fish going through the dam via the spillway and guided fish at the turbines.

- Forebay residence time, defined by the median, mean, and standard error that juvenile salmonids take to travel from the forebay entrance array $2 \mathrm{~km}$ upstream of the dam to when they pass into the dam (i.e., from $2 \mathrm{~km}$ upstream of the dam to the dam face)

- Tailrace egress time, defined as the median or mean time that juvenile salmonids take to travel through the dam to the downstream tailrace boundary $2 \mathrm{~km}$ downstream of the dam.

Results are reported for each performance measure. This report is designed to provide a succinct summary of $\mathrm{BiOp} /$ Fish Accords performance measures by treatment. A subsequent, comprehensive technical report will provide more detailed data about survival rates and fish passage at JDA in 2010.

\footnotetext{
${ }^{1}$ Performance as defined in the 2008 FCRPS BiOp, Section 6.0.
} 


\subsection{Report Contents}

Chapter 2.0 describes the methods used to evaluate salmonid passage, including handling, tagging and release procedures; signal processing; and statistical methods. Study results are presented in Chapter 3.0, followed by a discussion of the results in Chapter 4.0, and references in Chapter 5. Fish capture histories are presented in the Appendix. 


\subsection{Methods}

Study methods include fish handling, tagging, and release procedures; acoustic-tag detection and signal processing; and statistical and analytical approaches.

\subsection{Release-Recapture Design}

The release-recapture model used to estimate dam passage survival rates at JDA consisted of regrouping the detected fish as a virtual release $\left(\mathrm{V}_{2}\right)$ at the dam face (Figure 2.1) (Skalski et al. 2010). Tagged fish released above JDA at CR390 were used to supply a source of fish known to have arrived alive at the face of JDA. By releasing the fish far enough upstream, they should have arrived at the dam in a spatial pattern typical of run-of-river (ROR) fish. This virtual-release group was then used to estimate survival through the dam and through Lake Celilo to the detection array at the upstream face of TDA (CR309) (Figure 2.1). In the survival model, the dam-face detection array at the face of TDA was the primary array; the autonomous array (CR275), near Hood River, Oregon, was the secondary array; and the dam-face detection array at the face of Bonneville Dam (BON; CR234) was the tertiary array. The sizes of the releases of fish tagged with JSATS acoustic micro-transmitters used in the dam passage survival estimates are summarized in Table 2.1.

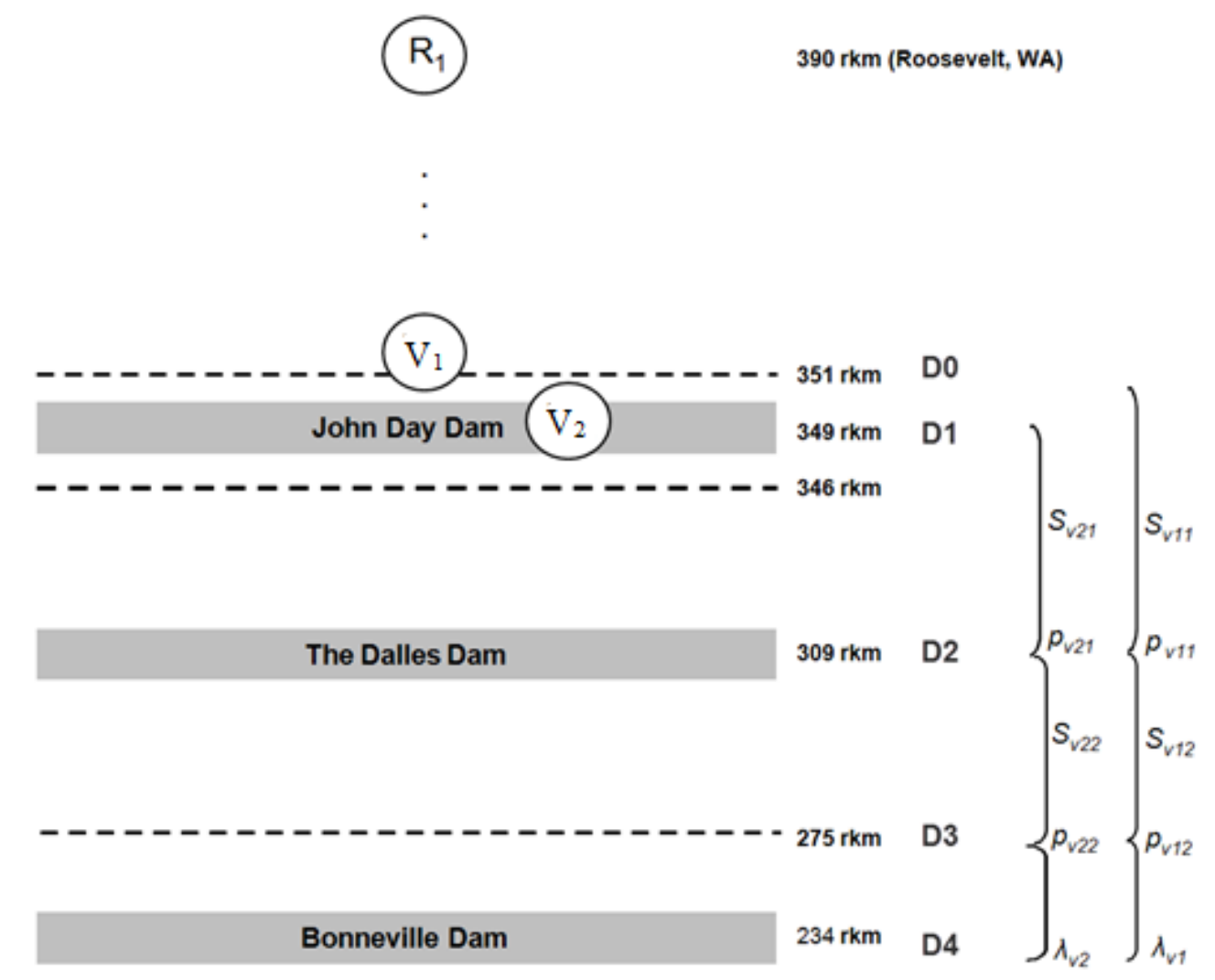

Figure 2.1. Schematic of the Single-Release Model Design Used to Estimate Dam Passage Survival from the John Day Dam Forebay and Dam-Face to The Dalles Dam $\left(\mathrm{S}_{\mathrm{v} 11}\right)$. The virtual releases $\left(\mathrm{V}_{1}, \mathrm{~V}_{2}\right)$ were composed of fish arriving at the forebay array or dam face from fish released at CR390 $\left(\mathrm{R}_{1}\right)$. 
Table 2.1. Sample Sizes of CHO Tagged with Acoustic Micro-Transmitters Released Above JDA near Roosevelt, Washington (CR390) in Summer 2010 and Regrouped as a Virtual Release at the Dam Face $\left(\mathrm{V}_{2}\right)$ to Estimate Dam Passage Survival

\begin{tabular}{lccc}
\hline & Total & \multicolumn{2}{c}{ Virtual Release } \\
\cline { 3 - 4 } Species & Released & $30 \%$ Spill & $40 \%$ Spill \\
\hline Subyearling Chinook salmon & 2849 & 1291 & 1344 \\
\hline
\end{tabular}

A three-dimensional (3D) double-detection array at the face of JDA was used to construct the virtualrelease group, and to identify powerhouse and spillway passage routes taken by fish passing through the dam. These passage-route data were used to calculate SPE at JDA. A total of 50 acoustic tags were randomly sampled from the tags used in the summer study for a tag-life assessment. The tags were activated, held in river water, and monitored continuously until they stopped transmitting. The information from the tag-life study was used to adjust the perceived survival estimates from the CormackJolly-Seber release-recapture model according to the methods of Townsend et al. (2006).

\subsubsection{Spill Treatments}

The effects of the $30 \%$ and $40 \%$ spill treatments on fish passage and survival rates during the summer study period were tested. The data collection period was designed to be from June 13 to August 5, 2010, but $30 \%$ and $40 \%$ spill treatments were only realized between June 13 and July 19, 2010. Spill treatment periods were selected according to a randomized block experimental design (Figure 2.2). The design called for nine 4-d blocks, each block consisted of two 2-d treatments randomly chosen to be $30 \%$ or $40 \%$ spill, followed by $2 \mathrm{~d}$ of the alternate treatment. Treatment order within a given block was randomized. Treatment changes were made at 0600 hours on a given day.

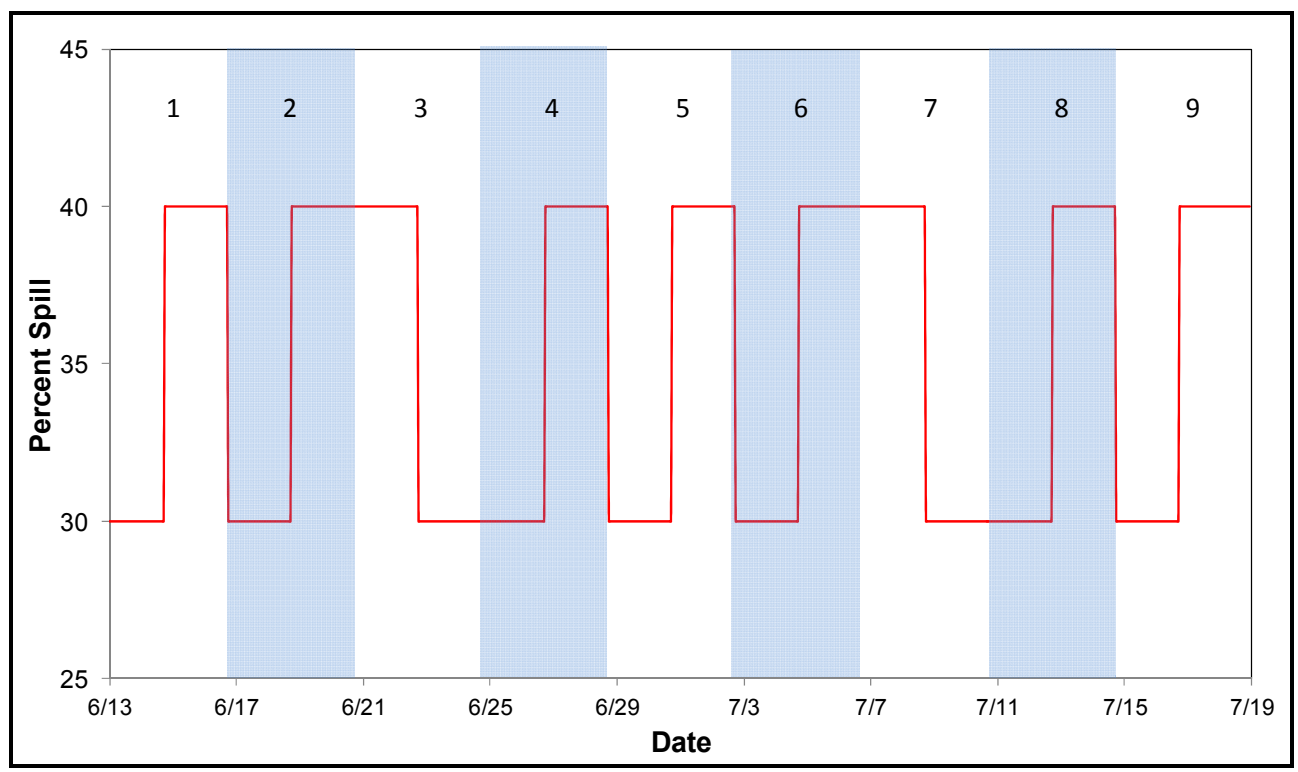

Figure 2.2. Spill Treatment Schedule for the Summer Season (June 13-July 19, 2010) at JDA. The design calls for nine treatment blocks (numbered) with two treatments (30\% or $40 \%$ spill) per block. 


\subsection{Handling, Tagging, and Release Procedures}

Fish obtained from the JDA juvenile bypass system (JBS) were surgically implanted with JSATS tags, held for $24 \mathrm{~h}$, and transported to Roosevelt, Washington (CR390), where they were released into the river, as described in the following sections.

\subsubsection{Acoustic Tags}

The acoustic tags used in the summer 2010 study were manufactured by Advanced Telemetry Systems. Each tag, model number ATS-156dB, measured $12.02 \mathrm{~mm}$ in length, $5.21 \mathrm{~mm}$ in width, $3.72 \mathrm{~mm}$ in thickness, and weighed $0.438 \mathrm{~g}$ in air. The tags had a nominal transmission rate of 1 pulse every $3 \mathrm{~s}$. Nominal tag life was expected to be about $23 \mathrm{~d}$.

\subsubsection{Fish Collection}

The $\mathrm{CH} 0$ used in the study were obtained from the JDA JBS. The PSMFC diverted fish from the JBS into an examination trough, as described by Martinson et al. (2006). Fish were evaluated and accepted for tagging using the following criteria:

- Qualifying (Acceptable) Conditions

- $\quad$ size $\geq 95 \mathrm{~mm}$

- visible elastomer tag(s) present or absent

- adipose-fin clipped or unclipped

- presence of trematodes, copepods, leeches

- short operculum

- healed (moderate) injuries (e.g., bird strikes)

$-\leq 3 \%$ fungal patch

- minor fin blood

- partial descaling (3-19\%)

- eroded pectoral or ventral fins

- Disqualifying Conditions

$-\quad \geq 20 \%$ descaling

- body punctures (showing blood, e.g., predator marks, bird strikes, head wounds, nose/snout injuries)

- obvious signs of bacterial kidney disease

- eye hemorrhage or pop eye

- $\quad>3 \%$ coverage with fungus

- deformed or emaciated

- holdovers (fish not $\mathrm{CHO}$ ) 
- passive integrated transponder (PIT)- or radio-tagged or other post-surgical fishes

- notable operculum damage (except short operculum)

- presence of columnaris, furuncles

- injured caudal peduncles

- injured caudal fins

- fin hemorrhage.

\subsubsection{Tagging Procedure}

Prior to surgery, fish were anesthetized in an 18.9-L "knockdown" bucket containing fresh river water and MS-222 (tricaine methanesulfonate; $80 \mathrm{mg} / \mathrm{L}$ ). Anesthesia buckets were refreshed repeatedly to maintain the temperature within $\pm 2^{\circ} \mathrm{C}$ of river temperature. Each fish was weighed and measured before tagging.

During surgery, each fish was placed ventral side up and a gravity-fed anesthesia supply line was placed into its mouth. The dilution of the "maintenance" anesthesia was $40 \mathrm{mg} / \mathrm{L}$. Using a surgical blade, a 6- to 8-mm incision was made in the body cavity between the pelvic girdle and pectoral fin. A PIT tag was inserted followed by an acoustic tag. Both tags were inserted toward the anterior end of the fish. The incision was closed using 5-0 Monocryl suture.

After closing the incision, the fish were placed in a light occlusive 18.9-L transport bucket filled with aerated river water. Fish were held in these buckets for 18 to $24 \mathrm{~h}$ before being transported for release into the river. The loading rate was five fish per bucket.

\subsubsection{Release Procedures}

All fish were tagged at JDA and transported by truck to CR390, upstream for release into the river at $\mathrm{R}_{1}$ (Figure 2.1). Upon arriving at a release site, fish buckets were transferred to a boat for transport to the in-river release location. Fish were released at each of five release locations across the width of the river channel, one bucket at a time. The purpose of this release strategy was to distribute fish in a way that better represents the actual spatial distribution of ROR fish.

Releases occurred for $32 \mathrm{~d}$ (June 13 to July 14, 2010). Releases alternated between day and night, every other day, over the course of the study. The timing of the releases was staggered to facilitate downstream mixing (Table 2.2).

Table 2.2. Release Times for the Fish Tagged with Acoustic Micro-Transmitters near Roosevelt, Washington

\begin{tabular}{ccc}
\hline & \multicolumn{2}{c}{ Release Times } \\
\cline { 2 - 3 } Release Location & Daytime & Nighttime \\
\hline $\mathrm{R}_{1}$, Roosevelt, WA (CR390) & Day 1: 0900 $\mathrm{h}$ & Day 2: $2000 \mathrm{~h}$ \\
\hline
\end{tabular}




\subsection{Acoustic Signal Processing}

Transmissions of JSATS tag codes received on cabled and autonomous hydrophones were recorded in raw data files. These files were downloaded periodically and transported to PNNL's North Bonneville office for processing. Receptions of tag codes within raw data files were processed to produce a data set of accepted tag detection events. For cabled arrays, detections from all hydrophones at a dam were combined for processing, using the following three filters:

- Multipath filter: For data from each individual cabled hydrophone, all tag-code receptions that occur within $0.156 \mathrm{~s}$ after an initial identical tag code reception were deleted under the assumption that closely lagging signals are multipath. Initial code receptions were retained. The delay of $0.156 \mathrm{~s}$ was the maximum acceptance window width for evaluating a pulse repetition interval (PRI) and was computed as 2 (PRI_Window+12×PRI_Increment). Both PRI_Window and PRI_Increment were set at 0.006 , which was chosen to be slightly larger than the potential rounding error in estimating PRI to two decimal places.

- Multi-detection filter: Receptions were retained only if the same tag code was received at another hydrophone in the same array within $0.3 \mathrm{~s}$ because receptions on separate hydrophones within $0.3 \mathrm{~s}$ (about $450 \mathrm{~m}$ of range) were likely from a single tag transmission.

- PRI filter: Only those series of receptions of a tag code (or "messages") that were consistent with the pattern of transmissions from a properly functioning JSATS acoustic tag were retained. Filtering rules were evaluated for each tag code individually, and it was assumed that only a single tag would be transmitting that code at any given time. For the cabled system, the PRI filter operated on a message, which included all receptions of the same transmission on multiple hydrophones within $0.3 \mathrm{~s}$. Message time was defined as the earliest reception time across all hydrophones for that message. Detection required that at least six messages were received with an appropriate time interval between the leading edges of successive messages.

The receptions of JSATS tag codes within raw data files from autonomous nodes were also processed to produce a data set of accepted tag-detection events. A single file was processed at a time, and no information about receptions at other nodes was used. The Multipath and PRI filters described above were used.

The output of this process was a data set of events that summarized accepted tag detections for all times and locations where hydrophones were operating. Each unique event record included a basic set of fields that indicated the unique identification number of the fish, the first and last detection time for the event, the location of detection, and how many messages were detected within the event. This list was combined with accepted tag detections from the autonomous arrays and PIT-tag detections for additional quality assurance/quality control analysis prior to survival analysis. Additional fields captured specialized information, where available. One such example was route of passage, which was assigned a value for events that immediately precede passage at a dam based on spatial tracking of tagged fish movements to a location of last detection. Multiple receptions of messages within an event can be used to triangulate successive tag position relative to hydrophone locations.

An important quality control step was examination of the sequence of detections for every tagged fish on all arrays above and below the dam-face array to identify any detection sequences that deviated from the expected upstream to downstream progression through arrays in the river. Except for possible 
detections on forebay entrance arrays after detection on a nearby dam-face array 1 to $3 \mathrm{~km}$ downstream, apparent upstream movements of tagged fish between arrays that were more than $5 \mathrm{~km}$ apart or separated by one or more dams were very rare $(<0.015 \%)$ and probably represented false positive detections on the upstream array. False positive detections usually have close to the minimum number of messages and are deleted from the event data set before survival analysis.

JSATS-tagged fish were tracked in 3D in the immediate forebay of JDA to determine routes of passage and to estimate SPE. Acoustic tracking is a common technique in bioacoustics based on time-ofarrival differences among different hydrophones. Usually, the process requires a three-hydrophone array for $2 \mathrm{D}$ tracking and a four-hydrophone array for 3D tracking. For this study, only 3D tracking was performed; methods used were similar to those described by Weiland et al. (2011).

\subsection{Statistical Methods}

Dam passage survival rates were estimated, tag life was analyzed, assumptions were tested, and SPE and FPE were estimated as described in the following sections.

\subsubsection{Estimation of Dam Passage Survival Rates}

Maximum likelihood estimation was used to estimate rates of dam passage survival at JDA. The capture histories from all replicate releases, both daytime and nighttime, were pooled for the analysis to produce a single season-wide estimate of survival. A joint likelihood model was used to estimate dam passage survival rates based on the virtual/single-release model corrected for tag life.

The estimate of dam passage survival was computed as a function of estimated survival rate from the dam-face array at JDA to the dam-face array at TDA (Figure 2.1) and corrected for the probabilities that the acoustic tags were still active, i.e.,

$$
\hat{S}_{\text {Dam }}=\left(\frac{\hat{S}_{1}}{\hat{L}_{1}}\right)
$$

where $\hat{L}_{1}$ is the estimated probability an acoustic tag is still active associated with the survival estimate

$\hat{S}_{1}$. The variance estimate for $\hat{S}_{\mathrm{Dam}}$ takes into account both the release-recapture sampling error and the error in the tag-life estimates according to Townsend et al. (2006). All calculations were performed using Program ATLAS (CBR 2012a) and cross-verified using Statistical Analysis Systems software and/or Program USER (CBR 2012b).

\subsubsection{Tag-Life Analysis}

The 50 acoustic tags randomly sampled from the tags used in the $\mathrm{CH} 0$ survival study were monitored continuously until tag failure. The failure times were fit to the four-parameter vitality model of $\mathrm{Li}$ and Anderson (2009). The vitality model tends to fit acoustic-tag failure times well, because it allows for both early onset of random failure due to manufacturing as well as systematic battery failure later on. 
The probability density function for the vitality model can be rewritten as

$$
f(t)=1-\left(\Phi\left(\frac{1-r t}{\sqrt{u^{2}+S^{2} t}}\right)-e^{\left(\frac{2 u^{2} r^{2}}{S^{4}}+\frac{2 r}{S^{2}}\right)} \Phi\left(\frac{2 u^{2} r+r t+1}{\sqrt{u^{2}+S^{2} t}}\right)\right)^{e^{-k t}}
$$

where $\Phi=$ cumulative normal distribution

$r=$ average wear rate of components

$S=$ standard deviation in wear rate

$k=$ rate of accidental failure

$u=$ standard deviation in quality of original components.

The random failure component, in addition to battery discharge, gives the vitality model additional latitude to fit tag-life data not found in other failure-time distributions such as the Weibull or Gompertz. Parameter estimation was based on maximum likelihood estimation.

For the virtual-release group $\left(\mathrm{V}_{1}\right)$ based on fish known to have arrived at the dam and with active tags, the conditional probability of tag activation, given the tag was active at the detection array at CR309, was used in the tag-life adjustment for that release group. The conditional probability of tag activation at time $t_{1}$, given it was active at time $t_{0}$, was computed by the following quotient:

$$
P\left(t_{1} \mid t_{0}\right)=\frac{S\left(t_{1}\right)}{S\left(t_{0}\right)}
$$

\subsubsection{Tests of Assumptions}

Detections at multiple locations downstream of the single fish release site at Roosevelt, Washington, provided data required to estimate virtual-release reach survival rates based on the single releaserecapture model. Tests of assumptions are described in the following sections.

\subsubsection{Burnham et al. (1987) Tests}

Tests 2 and 3 of Burnham et al. (1987) have been used to assess whether upstream detection history has an effect on downstream survival. Such tests are most appropriate when fish are physically recaptured or segregated during capture as in the case of PIT-tagged fish going through the JBS. However, acoustic-tag studies do not use physical recaptures to detect fish. Consequently, there is little or no relevance of these tests in acoustic-tag studies. Furthermore, the very high detection probabilities present in acoustic-tag studies frequently preclude calculation of these tests. For these reasons, these tests were not performed.

\subsubsection{Tests of Mixing}

There were no downstream reference releases of fish downstream of JDA; therefore, there was no need to test for mixing in the common tailwater. 


\subsubsection{Tagger Effects}

Subtle differences in handling and tagging techniques can have an effect on the survival rate of juvenile salmonids tagged with acoustic micro-transmitters used in the estimation of dam passage survival. For this reason, tagger effects on $\mathrm{CH} 0$ were evaluated as part of the study at JDA. In that analysis, the single release-recapture model was used to estimate reach survival rates for fish tagged by different individuals. The analysis evaluated whether any consistent pattern of reduced reach survival rates existed for fish tagged by any of the tagging staff.

For $k$ independent reach survival rate estimates, a test of equal survival rate was performed using the $F$-test

$$
F_{k-1, \infty}=\frac{s_{\hat{S}}^{2}}{\left(\frac{\sum_{i=1}^{k} \operatorname{Var}\left(\hat{S}_{i} \mid S_{i}\right)}{k}\right)},
$$

where $s_{\hat{S}}^{2}=\frac{\sum_{i=1}^{k}\left(\hat{S}_{i}-\hat{\bar{S}}\right)^{2}}{k-1}$ and $\hat{\bar{S}}=\frac{\sum_{i=1}^{k} \hat{S}_{i}}{k}$.

The $F$-test was used in evaluating tagger effects.

\subsubsection{Estimation of Travel Times}

Travel times associated with forebay residence time and tailrace egress time $\bar{t}$ were estimated using medians because a few high estimates tended to bias the mean estimates.

We estimated the variance of $\bar{t}$ by

$$
\widehat{\operatorname{Var}}(\bar{t})=\frac{\sum_{i=1}^{n}\left(t_{i}-\bar{t}\right)^{2}}{n(n-1)}
$$

where $t_{i}$ was the travel time of the $i$ th fish $(i=1, \ldots, n)$.

Travel times were estimated as follows:

1. Forebay residence time was calculated as the difference between the time of last detection on the dam-face array and the time of first detection on the forebay entrance array.

2. The $100-\mathrm{m}$ forebay residence time was calculated as the difference between the time of last detection on the dam-face array and the time of first detection $100 \mathrm{~m}$ upstream of the dam on the dam-face array.

3. Tailrace egress time was calculated as the difference between the time of last detection on the egress array and the time of last detection on the dam-face array. 


\subsubsection{Estimation of Spill Passage Efficiency}

By definition in the Fish Accords, SPE is the number of fish passing at the spillway relative to the number of fish passing the entire dam. Consequently, SPE was estimated by the fraction

$$
\widehat{\mathrm{SPE}}=\frac{\hat{N}_{S P}}{\hat{N}_{S P}+\hat{N}_{P H}},
$$

where $\hat{N}_{i}$ is the estimated abundance of fish tagged with JSATS acoustic micro-transmitters through the $i$ th route $(i=$ spillway $[\mathrm{SP}]$ or powerhouse $[\mathrm{PH}]$ ). The dam-face detection array was used to estimate absolute abundance $(N)$ through a route using the single mark-recapture model (Seber 1982, p. 60) independently at each route. We calculated the variance as follows:

$$
\begin{aligned}
\operatorname{Var}(\widehat{\mathrm{SPE}})= & \frac{\widehat{\mathrm{SPE}}(1-\widehat{\mathrm{SPE}})}{\sum_{i=1}^{3} \hat{N}_{i}}+\widehat{\mathrm{SPE}}^{2}(1-\widehat{\mathrm{SPE}})^{2} \\
& \cdot\left[\frac{\operatorname{Var}\left(\hat{N}_{S P}\right)}{\left(\hat{N}_{S P}\right)^{2}}+\frac{\widehat{\operatorname{Var}}\left(\hat{N}_{P H}\right)}{\hat{N}_{P H}^{2}}\right] .
\end{aligned}
$$

\subsubsection{Estimation of Fish Passage Efficiency}

Fish passage was estimated from several passage efficiencies (e.g., SPE, TSW-passage efficiency, and JBS-passage efficiency). FPE is defined as the proportion of fish that pass through the dam through non-turbine routes (i.e., spill, TSW, or JBS). FPE was estimated by the sum of the proportions of nonturbine passage proportions:

$$
\widehat{\mathrm{FPE}}=\hat{P}_{\mathrm{SP}}+\hat{P}_{\mathrm{TSW}}+\hat{P}_{\mathrm{JBS}}
$$

The variance of FPE was estimated as

$$
\begin{aligned}
\widehat{\operatorname{Var}}(\widehat{\mathrm{FPE}})= & \frac{\widehat{\mathrm{FPE}}(1-\widehat{\mathrm{FPE}})}{\hat{N}}+\widehat{\mathrm{FPE}}^{2}(1-\widehat{\mathrm{FPE}})^{2} \\
& \cdot\left[\frac{\widehat{\operatorname{Var}}\left(\hat{N}_{\mathrm{PH}}\right)}{\hat{N}_{\mathrm{PH}}^{2}}+\frac{\widehat{\operatorname{Var}}\left(\hat{N}_{\mathrm{SP}}\right)+\widehat{\operatorname{Var}}\left(\hat{N}_{\mathrm{TSW}}\right)+\widehat{\operatorname{Var}}\left(\hat{N}_{\mathrm{JBS}}\right)}{\left(\hat{N}_{\mathrm{SP}}+\hat{N}_{\mathrm{TSW}}+\hat{N}_{\mathrm{JBS}}\right)^{2}}\right] .
\end{aligned}
$$




\subsection{Results}

This section contains study findings, including discharge and spill conditions; fish size distribution; handling mortality and tag shedding; tagger effects; tag-life corrections; arrival distributions; dam passage survival; forebay, 100-m forebay residence times; tailrace egress, and metrics of passage efficiency.

\subsection{Project Discharge}

The total project discharge during the summer 2010 survival study at JDA was higher for the first half of the summer season than the 10-y (2000-2009) average conditions (Figure 3.1). Daily total project discharge during the study period ranged from 146 to $363 \mathrm{kcfs}$ with an average discharge of $224 \mathrm{kcfs}$ (June 13 to August 5, 2010).

Forebay elevation averaged $263.3 \mathrm{ft}$ during the study period and ranged $0.5 \mathrm{ft}$, referenced to mean sea level.

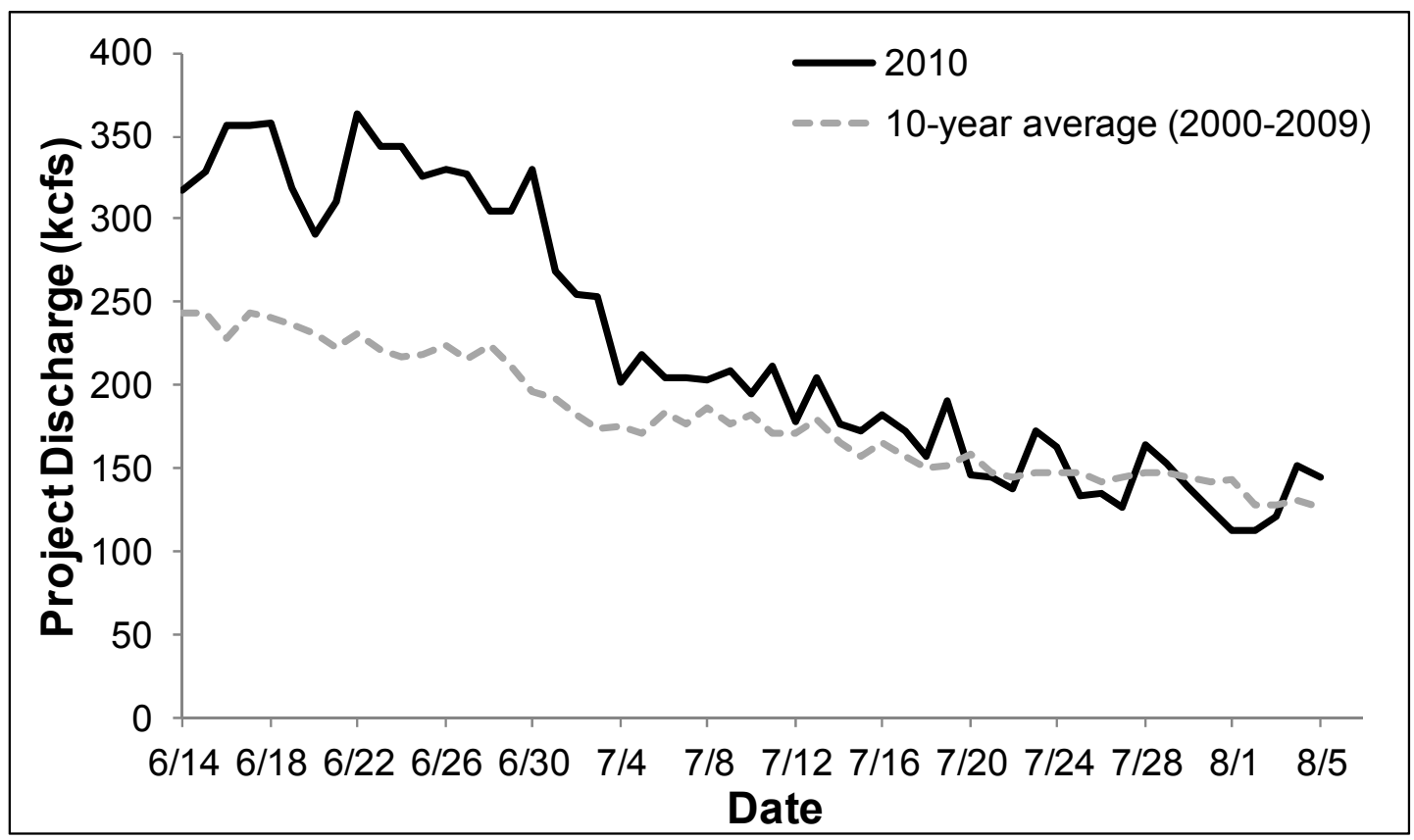

Figure 3.1. Average Daily Water Discharge (kcfs) from JDA During the Summer 2010 Study and for the Preceding 10-Year Period (2000 to 2009)

\subsection{Spill Treatments}

During the summer 2010 tagging effort, treatment conditions were generally maintained for each of the nine treatment blocks, for which there were two 2-d treatments per block. A small deviation from the prescribed treatments during block 1 of summer was the result of required spill operational adjustments made by operators at JDA (Figure 3.2). 


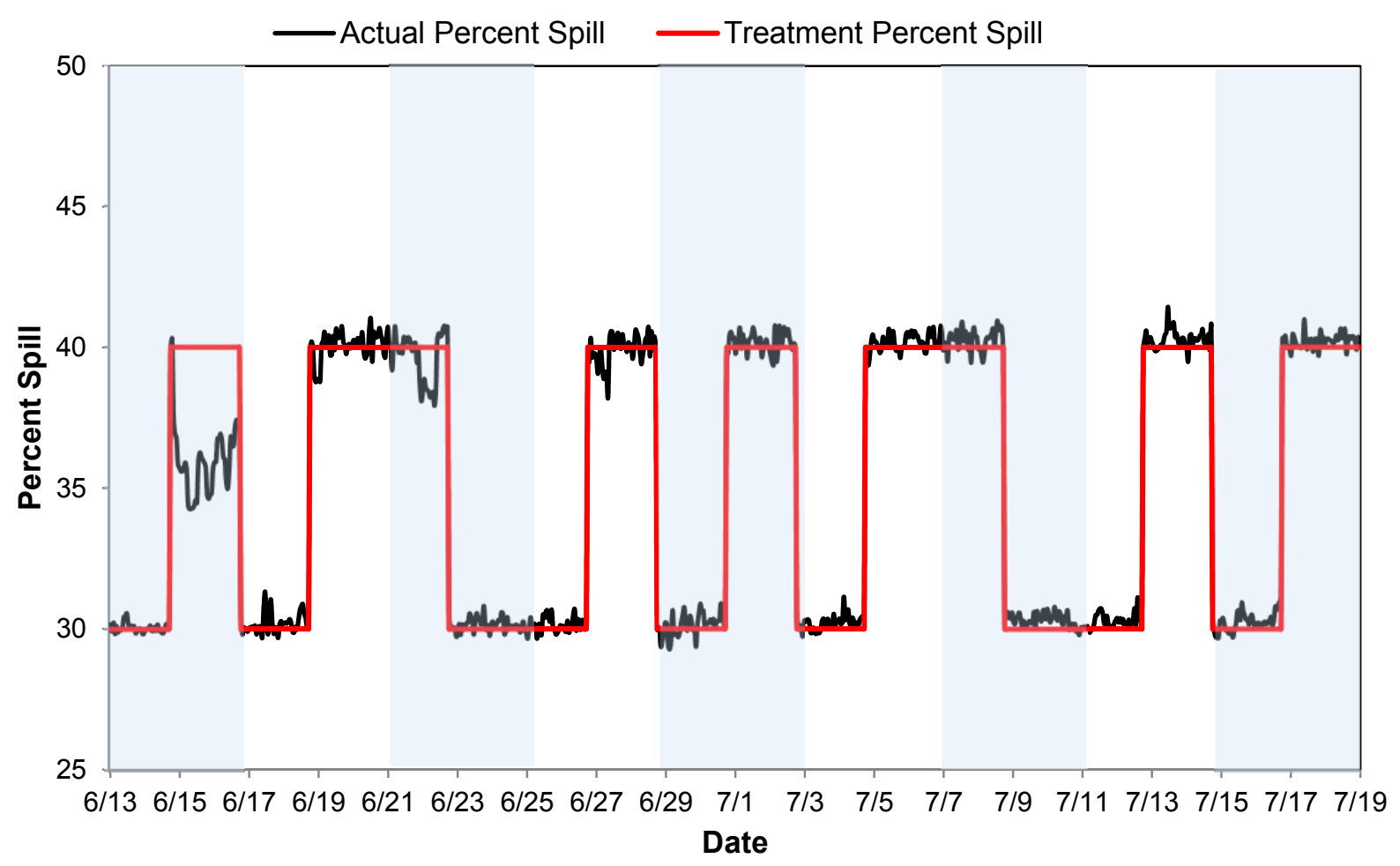

Figure 3.2. Spill Treatments for the Summer Study at JDA, June 13 Through July 19, 2010. There were nine treatment blocks with two 2-d treatments per block, with the exception of block 1, which did not attain $40 \%$ spill.

\subsection{Assessment of Assumptions}

This section of the report covers the assessment of assumptions, including fish size distribution, taglife corrections, handling mortality and tag shedding, and tagger effects. Downstream mixing and arrival distributions were not included in the test of assumptions because a single-release survival model was used.

\subsubsection{Fish Size Distribution}

Comparison of fish, tagged with acoustic micro-transmitters, with ROR fish sampled at JDA as part of the Smolt Monitoring Program shows that the length frequency distributions were slightly offset for $\mathrm{CH0}$ (Figure 3.3) because fish less than $95 \mathrm{~mm}$ in length were rejected as tagging candidates. $\mathrm{CH0}$, as sampled by the Smolt Monitoring Program, had a median length of $104 \mathrm{~mm}$, compared to $110 \mathrm{~mm}$ for $\mathrm{CHO}$ tagged with acoustic micro-transmitters. 


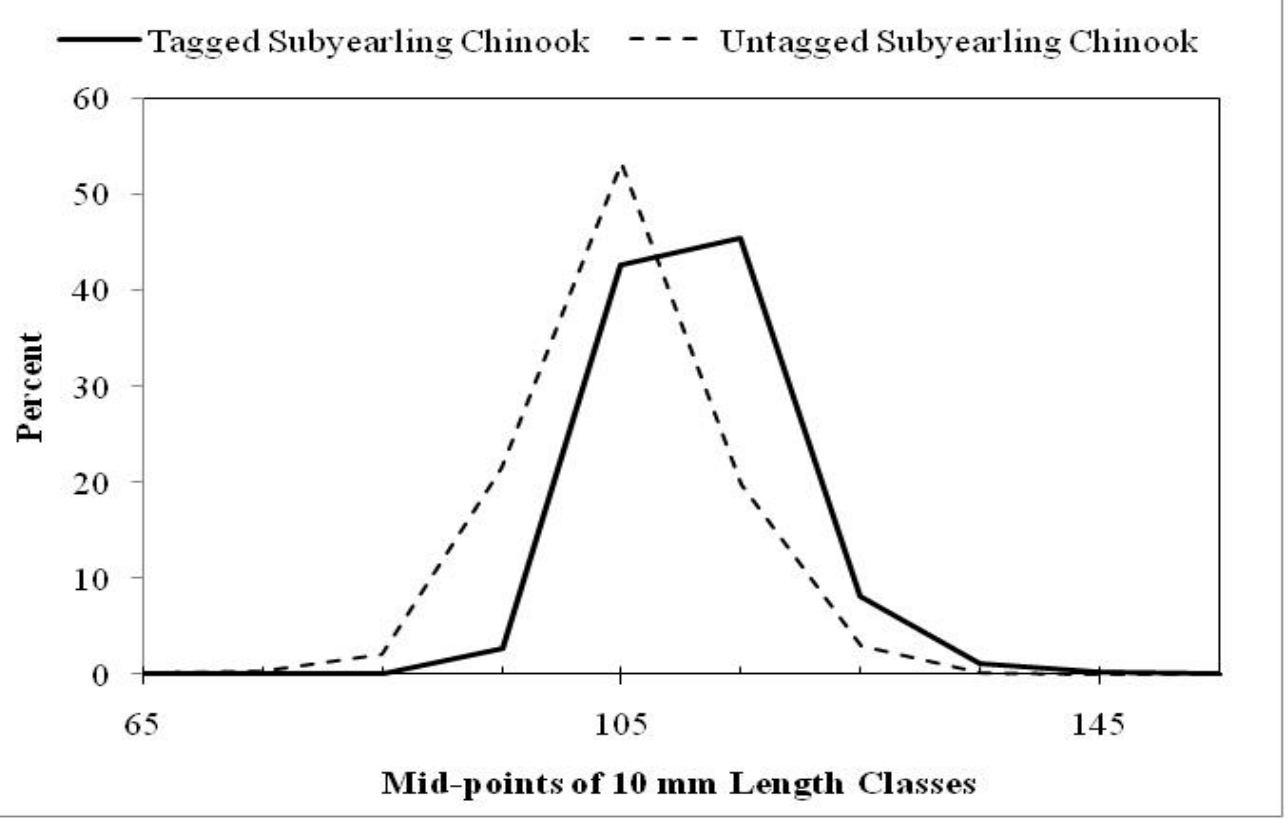

Figure 3.3. Relative Frequency Distributions for Fish Length ( $\mathrm{mm})$ of CH0 Sampled at JDA, Summer 2010

\subsection{Fish Collection}

Of the $5645 \mathrm{CH} 0$ collected in summer 2010, 4449 were tagged and released alive for the survival studies at JDA, TDA, and BON. In addition, $67 \mathrm{CH} 0$ were tagged and released dead to validate that dead fish were not being detected on downstream arrays. Table 3.1 provides a summary of all $\mathrm{CH} 0$ collected for the studies and their fates. The number of fish rejected due to maladies and the reasons for their rejection are provided in Table 3.2 and the number of and reasons that fish were excluded for other reasons are provided in Table 3.3 .

Table 3.1. Summary of the Number and Percent of Fish Rejected, Excluded, Tagged and Released Alive, Tagged and Released Dead, and that Exceeded Collection Needs. Totals represent the number and percent collected in 2010 .

\begin{tabular}{lrc}
\hline \multicolumn{1}{c}{ Fate Statistics } & $n$ & $\%$ \\
\hline Rejected $^{(\text {a) }}$ & 430 & 7.6 \\
Excluded $^{(\mathrm{b})}$ & 330 & 5.8 \\
Tagged and Released Live & 4449 & 78.8 \\
Tagged and Released Dead $^{(\mathrm{c})}$ & 67 & 1.2 \\
Extra Fish $^{(\mathrm{d})}$ & 369 & 6.5 \\
\hline Collected & $\mathbf{5 6 4 5}$ & $\mathbf{1 0 0 . 0}$ \\
\hline
\end{tabular}

(a) Because of maladies.

(b) Too short, too long, previously tagged, dead, wrong species, dropped, or jumped.

(c) Beyond overnight mortalities, others were sacrificed.

(d) Collected but not evaluated before the tagging quota was met. 
Table 3.2. Rejection Numbers and Percentages due to Fish Maladies

\begin{tabular}{lrr}
\hline \multirow{2}{*}{ Malady Description } & \multicolumn{2}{c}{$\mathrm{CH} 0$} \\
\cline { 2 - 3 } Bacterial Kidney Disease & 2 & 0.5 \\
Descaling $(\geq 20 \%)$ & 226 & 52.6 \\
Emaciated & 1 & 0.2 \\
Exophthalmia & 5 & 1.2 \\
Fin Rot & 5 & 1.2 \\
Fungus & 9 & 2.1 \\
Hemorrhaging & 5 & 1.2 \\
Lacerations & 69 & 16.0 \\
Lesions & 26 & 6.0 \\
Operculum Damage & 33 & 7.7 \\
Other & 4 & 0.9 \\
Parasites & 34 & 7.9 \\
Skeletal Deformities & 11 & 2.6 \\
\hline Total & $\mathbf{4 3 0}$ & $\mathbf{1 0 0 . 0}$ \\
\hline
\end{tabular}

Table 3.3. Exclusion Numbers and Percentages Due to Failure to Meet Study Criteria

\begin{tabular}{lrr}
\hline & \multicolumn{2}{c}{ CH0 } \\
\cline { 2 - 3 } \multicolumn{1}{c}{ Reason for Exclusion } & \multicolumn{1}{c}{$\mathrm{n}$} & \multicolumn{1}{c}{$\%$} \\
\hline Moribund & 2 & 0.6 \\
Previously Tagged & 120 & 36.4 \\
$<95$ or $>260 \mathrm{~mm}$ & 202 & 61.2 \\
Wrong Species & 5 & 1.5 \\
Dropped/Jumped & 1 & 0.3 \\
\hline Total & $\mathbf{3 3 0}$ & $\mathbf{1 0 0 . 0}$ \\
\hline
\end{tabular}

\subsection{Handling Mortality and Tag Shedding}

Fish were held for $24 \mathrm{~h}$ prior to release. The 24 -h tagging mortality in summer was $0.35 \%$. No tags were shed during the 24-h holding period.

\subsection{Tag-Life Corrections}

Mean tag life $(n=50)$ was $35.54 \mathrm{~d}$. A tag-life correction was not applied to estimates of survival because nearly $100 \%$ of $\mathrm{CH} 0$ were expected to pass the tertiary array at BON (CR234) before tag life became problematic. Nonetheless, the following is an example of how a tag-life correction would have been estimated for summer. 
The earliest tag failure was at $31.27 \mathrm{~d}$ and the longest at $40.13 \mathrm{~d}$. The failure-time data for the acoustic tags was fit to a four-parameter vitality model of $\mathrm{Li}$ and Anderson (2009). The maximum likelihood estimates for the four model parameters were $\hat{r}=0.028261, \hat{s}=-2.91111 \times 10^{-9}, \hat{k}=0$, and $\hat{u}=0.058789$ (Figure 3.4).

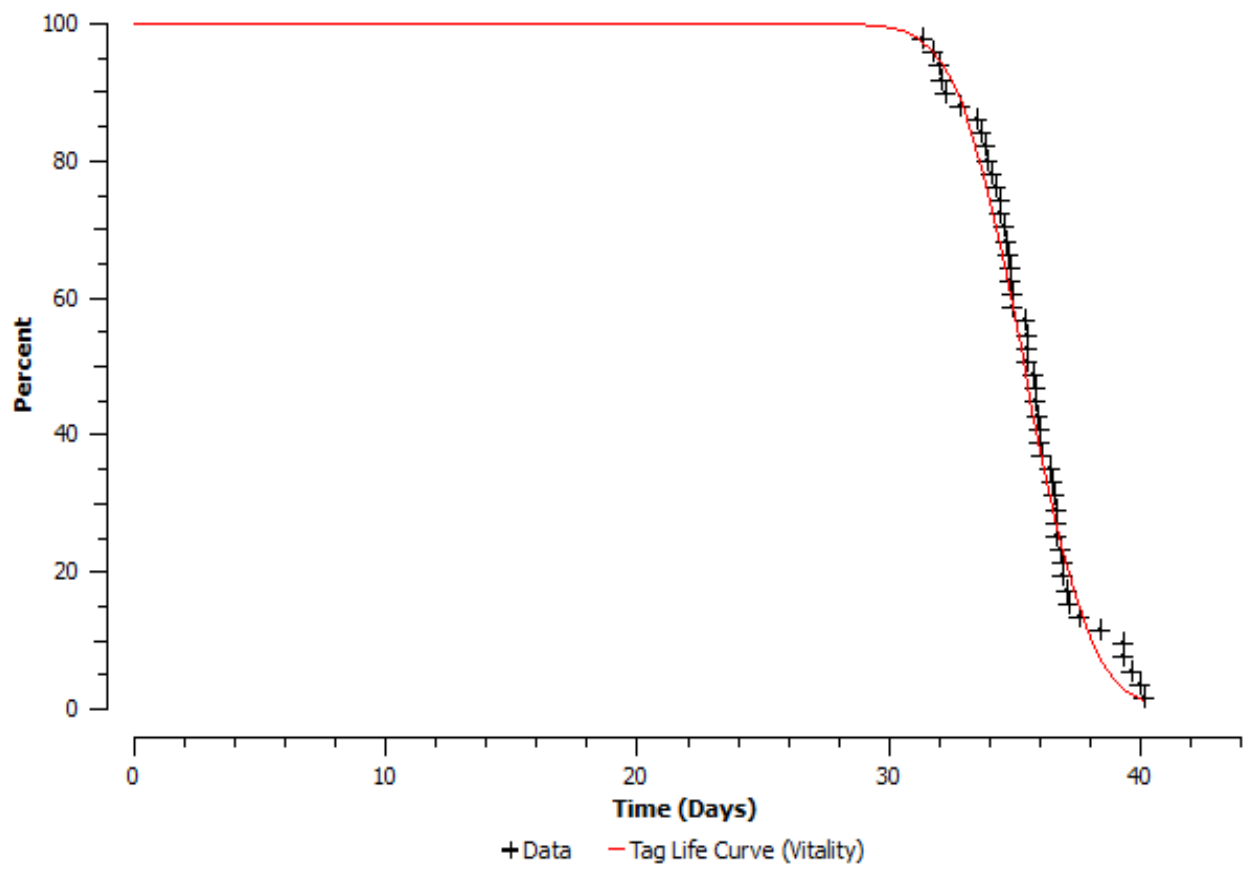

Figure 3.4. Individual Failure Times for the $n=50$ Acoustic Tags Used in the Tag-Life Study, Along with the Fitted Four-Parameter Vitality Model of Li and Anderson (2009)

\subsection{Arrival Distributions}

The estimated probability that an acoustic tag was active when a fish arrives at a downstream detection array depended on the tag-life curve and the distribution of observed travel times. These probabilities were calculated by integrating the tag-life survivorship curve (Figure 3.4) with the observed distribution of fish arrival times (i.e., time from tag activation to arrival).

The last detection array used in the survival analysis was the tertiary dam-face array at BON (CR234; Figure 2.1). The plot of arrival distributions at the $\mathrm{BON}$ dam-face array indicates that near $100 \%$ of $\mathrm{CH} 0$ (Figure 3.5) should have arrived well before tag failure became problematic. 


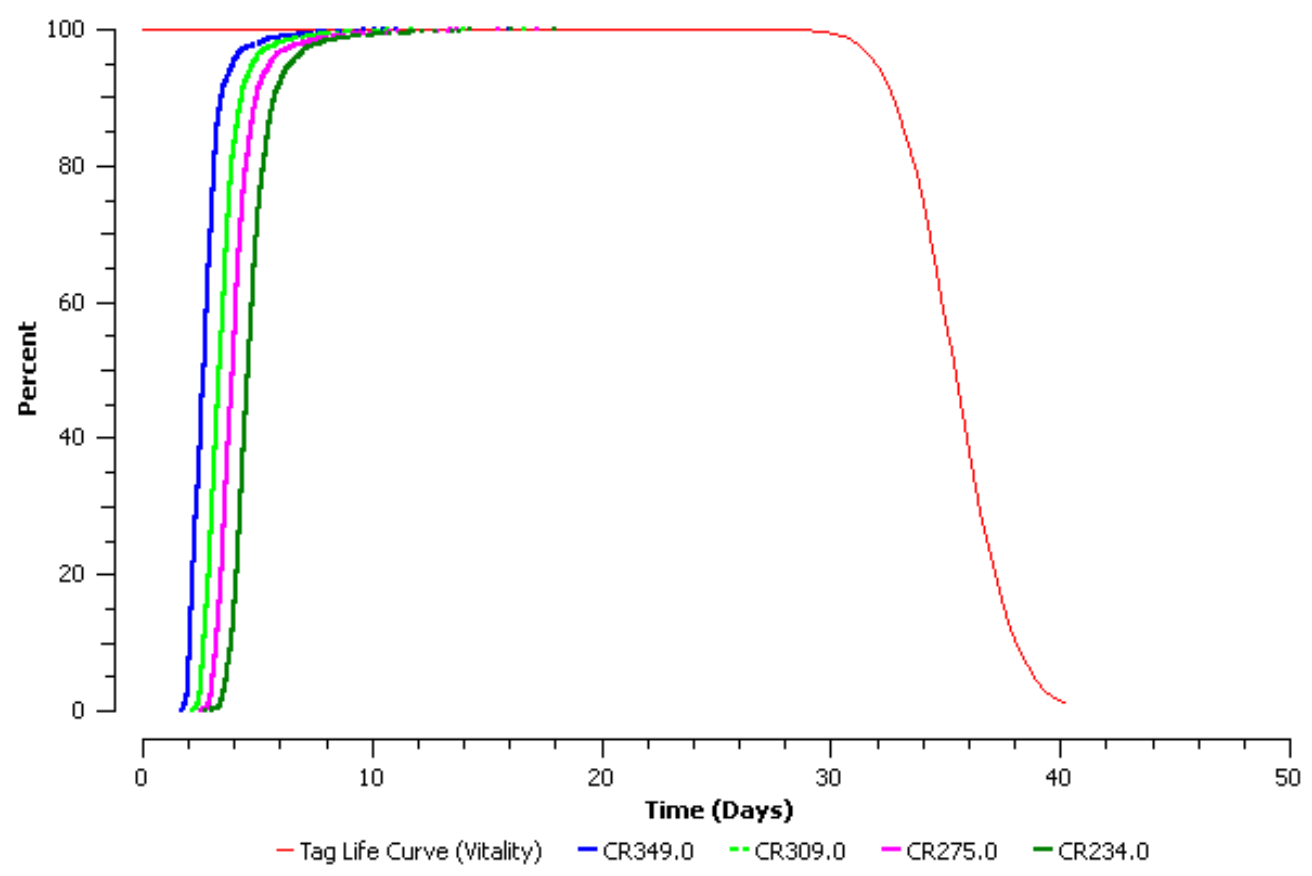

Figure 3.5. Plot of the Fitted Tag-Life Survivorship Curve and the Cumulative Arrival-Time Distributions of CH0 at the JDA Dam-Face Array ( $\mathrm{V}_{2}$; CR349), TDA Dam-Face Array (CR309), the Hood River Autonomous Node Array (CR275), and the BON Dam-Face Array (CR234)

\subsection{Examination of Tagger Effects}

Having various fish surgeons tag the same proportions of fish minimized, but did not necessarily eliminate, handling effects during the survival study. The study was therefore designed to balance tagger effort across all locations (Table 3.1, Skalski et al. 2010).

For $\mathrm{CH0}$, significant $(P<0.05)$ heterogeneity in survival rates between taggers was detected (Table 3.4). However, further examination indicated that seasonal trends in survival rates were confounding attempts to assess the presence of tagger effects using the $F$-tests because the effect of the various taggers was not evenly distributed across the course of the study (Table 3.5). Fish tagged by tagger $\mathrm{G}$ had lower survival rates because that staff member only tagged fish towards the end of the season. On the other hand, fish tagged by tagger B had very good survival rates because that staff member only tagged fish at the beginning of the study. Fish tagged by the remaining taggers had homogeneous survival rates because the taggers tagged fish more or less across the breadth of the season. When fish tagged by different staff during the same time, including tagger B and G, were examined, survival rates were found to be homogeneous and had no obvious evidence of any tagger effect. Therefore, fish tagged by all taggers were included in the analysis for this report. 
Table 3.4. Number of $\mathrm{CH} 0$ Tagged for Release at $\mathrm{R}_{1}$ by Tagger

\begin{tabular}{ccccccccc}
\hline & \multicolumn{7}{c}{ Tagger } & Total \\
\cline { 2 - 7 } Release Location & $\mathrm{A}$ & $\mathrm{B}$ & $\mathrm{C}$ & $\mathrm{D}$ & $\mathrm{E}$ & $\mathrm{F}$ & $\mathrm{G}$ & 2849 \\
\hline $\mathrm{R}_{1}$ & 436 & 489 & 463 & 454 & 171 & 369 & 467 & $\mathbf{2 8}$ \\
\hline
\end{tabular}

Table 3.5. Cormack-Jolly-Seber Estimates of Reach Survival Rates by Tagger for Subyearling Chinook Salmon. $F$-tests below each release and reach test for homogeneity of survival rates across taggers. No tests were significant $(\alpha<0.05)$. Red numbers indicate highest survival rate (1) to lowest survival rate (7).

\begin{tabular}{|c|c|c|c|c|c|c|c|}
\hline \multirow[b]{2}{*}{ Tagger } & & \multicolumn{2}{|c|}{ Release to CR309 } & \multicolumn{2}{|c|}{ CR309 to CR275 } & \multicolumn{2}{|c|}{ CR275 to CR234 } \\
\hline & & Estimate & SE & Estimate & SE & Estimate & SE \\
\hline A & & $0.8395(5)$ & 0.0177 & $0.9141(4)$ & 0.0147 & $0.9671(5)$ & 0.0104 \\
\hline B & & $0.8938(2)$ & 0.0141 & $0.9394(3)$ & 0.0115 & $1.0000(2)$ & 0.0044 \\
\hline $\mathrm{C}$ & & $0.8522(4)$ & 0.0165 & $0.9465(2)$ & 0.0114 & $1.0000(2)$ & 0.0000 \\
\hline D & & $0.8027(6)$ & 0.0187 & $0.9033(5)$ & 0.0155 & $0.9520(6)$ & 0.0124 \\
\hline $\mathrm{E}$ & & $0.9357(1)$ & 0.0188 & $0.9562(1)$ & 0.0162 & $1.0000(2)$ & 0.0000 \\
\hline $\mathrm{F}$ & & $0.8910(3)$ & 0.0163 & $0.9016(6)$ & 0.0165 & $0.9879(4)$ & 0.0068 \\
\hline G & & $0.7795(7)$ & 0.0194 & $0.8908(7)$ & 0.0165 & $0.9515(7)$ & 0.0138 \\
\hline All & $F$-test & 9.8531 & & 2.9625 & & 6.8130 & \\
\hline Taggers & $P$-value & $<0.0001$ & & 0.0068 & & $<0.0001$ & \\
\hline Tagger G & $F$-test & 7.5949 & & 2.6425 & & 7.6624 & \\
\hline Omitted & $P$-value & $<0.0001$ & & 0.0215 & & $<0.0001$ & \\
\hline
\end{tabular}

\subsection{Survival and Passage Estimates}

Dam passage survival rates were calculated from the dam face at JDA to the dam face at TDA. Survival rates from the forebay to TDA were calculated from the forebay array $2 \mathrm{rkm}$ upstream of JDA, past the dam to the dam face at TDA. Survival estimates were based on the virtual/single-release model using capture-history data and the fitted tag-life curve (Figure 3.5).

\subsubsection{Passage Survival to TDA}

The estimates of dam passage survival were based on the virtual/single-release model using capturehistory data (see Appendix). Single-release survival estimates $[\hat{S}( \pm \mathrm{SE})]$ were calculated for $2660 \mathrm{CH} 0$ released at Roosevelt, Washington (CR390), and regrouped at JDA (Table 3.6). These fish were regrouped at the dam face of JDA (CR349) to form virtual-release groups $\left(\mathrm{V}_{2}\right)$. Survival estimates for dam passage and by spill treatment are provided in Table 3.3. Dam passage survival rates from the upstream dam face of JDA to the dam face at TDA (CR309) did not meet the 93\% survival requirement defined in the $\mathrm{BiOp}$, but this was not designed as a compliance study and a single-release model was used. Results do show that the precision estimate was met.

Survival rates were similar for fish virtually released from the face of JDA $(0.908 \pm 0.006)$ or released at the JDA forebay entrance array $(0.904 \pm 0.006)$ suggesting low forebay loss (Table 3.3). Survival 
estimates did not meet the $93 \%$ criteria for spillway or TSW passed fish, but non-TSW passed fish were observed with a higher rate of survival $(0.937 \pm 0.007)$. Survival rate through spill bay 20 (preseason reconstruction of flow deflector) was lower than any other route through the spillway $(0.891 \pm 0.027)$. $\mathrm{CH} 0$ that passed through the JBS were observed with the highest survival rate $(0.947 \pm 0.013)$ contrasted to the lowest survival rate observed for turbine passed fish $(0.818 \pm 0.022)$.

Table 3.6. Estimates of Survival Rates for CHO Passing JDA Through Various Routes and Traveling to the Upstream Face of TDA in Summer 2010. Estimates were not corrected for tag life.

\begin{tabular}{lc}
\hline \multicolumn{1}{c}{ Route } & Survival Estimate \\
\hline Dam passage to TDA & $0.908(\widehat{\mathrm{SE}}=0.006)$ \\
Forebay entrance array to TDA & $0.904(\widehat{\mathrm{SE}}=0.006)$ \\
\hline
\end{tabular}

\subsubsection{Spill Treatment Effects on Survival Rate}

There was no significant difference in the survival of $\mathrm{CH} 0$ passing JDA during $30 \%$ and $40 \%$ spill treatments (Table 3.7, $P>0.05$ ). The route-specific survival was not significantly different between treatments for spillway, TSW, non-TSW, or bay 20 passage.

Table 3.7. Estimates of Survival Rates for $\mathrm{CH} 0$ Passing JDA through Various Routes and Traveling to the Upstream Face of TDA (CR309) During 30\% and 40\% Spill Treatments in Summer 2010. Estimates were not corrected for tag life.

\begin{tabular}{lccc}
\hline \multicolumn{1}{c}{ Metric } & Combined Spill & $30 \%$ Spill & $40 \%$ Spill \\
\hline Dam passage to TDA & $0.908(\widehat{\mathrm{SE}}=0.006)$ & $0.919(\widehat{\mathrm{SE}}=0.008)$ & $0.914(\widehat{\mathrm{SE}}=0.008)$ \\
Forebay entrance array to TDA & $0.904(\widehat{\mathrm{SE}}=0.006)$ & $0.915(\widehat{\mathrm{SE}}=0.008)$ & $0.907(\widehat{\mathrm{SE}}=0.008)$ \\
\hline
\end{tabular}

\subsection{Forebay Residence Time}

The forebay residence time is calculated as the time elapsed from the first detection on the forebay entrance array until the last detection on the dam-face array. Median forebay residence times for $\mathrm{CHO}$ were less than $2 \mathrm{~h}$ and similar across spill treatments (Table 3.8).

Table 3.8. Median and Mean Estimated Forebay Residence Time (h) for CH0 at JDA in 2010

\begin{tabular}{lccc}
\hline \multicolumn{1}{c}{ Treatment } & $\begin{array}{c}\text { Median } \\
\text { Time }(\mathrm{h})\end{array}$ & $\begin{array}{c}\text { Mean } \\
\text { Time }(\mathrm{h})\end{array}$ & SE \\
\hline All & 1.829 & 3.83 & 0.174 \\
$30 \%$ Spill & 1.949 & 4.00 & 0.258 \\
$40 \%$ Spill & 1.759 & 3.67 & 0.233 \\
\hline
\end{tabular}




\subsection{0-m Forebay Residence Time}

The 100-m forebay residence times were based on the time elapsed from the first detection within $100 \mathrm{~m}$ of the dam face to the last detection at the double array at the dam face of JDA. The timing of the first detection within $100 \mathrm{~m}$ of the dam was based on 3D tracking of the fish tagged with acoustic microtransmitters and interpretation of the time when the fish first crossed the 100-m distance threshold. Median forebay residence times for $\mathrm{CH} 0$ were less than $0.4 \mathrm{~h}$ and similar across spill treatments (Table 3.9).

Table 3.9. Median and Mean Estimated 100-m Residence Time (h) for $\mathrm{CH} 0$ at JDA in 2010

\begin{tabular}{lrcc}
\hline Treatment & $\begin{array}{c}\text { Median } \\
\text { Time (h) }\end{array}$ & $\begin{array}{c}\text { Mean } \\
\text { Time (h) }\end{array}$ & SE \\
\hline All & 0.289 & 2.06 & 0.160 \\
30\% Spill & 0.362 & 2.30 & 0.241 \\
40\% Spill & 0.259 & 1.83 & 0.214 \\
\hline
\end{tabular}

\subsection{Tailrace Egress Time}

The tailrace egress times were calculated based on the time elapsed from the last detection at the damface array to the last detection at the tailrace egress array (CR346). Median tailrace egress time for CH0 was less than $0.7 \mathrm{~h}$ and similar across spill treatments (Table 3.10).

Table 3.10. Estimated Median and Mean Tailrace Egress Time (h) for $\mathrm{CH} 0$ at JDA in 2010

\begin{tabular}{lrcc}
\hline \multicolumn{1}{c}{ Treatment } & $\begin{array}{c}\text { Median } \\
\text { Time (h) }\end{array}$ & $\begin{array}{c}\text { Mean } \\
\text { Time (h) }\end{array}$ & SE \\
\hline All & 0.618 & 1.94 & 0.355 \\
$30 \%$ Spill & 0.572 & 1.60 & 0.142 \\
$40 \%$ Spill & 0.564 & 2.18 & 0.691 \\
\hline
\end{tabular}

\subsection{Passage Efficiency Metrics}

During summer 2010, FPE for $\mathrm{CH} 0$ at JDA was $0.883 \pm 0.006$. SPE was $0.776 \pm 0.008$, relative to total dam passage. FPE and SPE were significantly different between the $30 \%$ and $40 \%$ spill treatments for $\mathrm{CHO}(P<0.05)$. Efficiency estimates can be found in Table 3.11. 
Table 3.11. Summary of Other Performance Metrics at John Day Dam, Summer 2010

\begin{tabular}{|c|c|c|c|}
\hline Metric & Combined Spill & $30 \%$ Spill & $40 \%$ Spill \\
\hline Fish Passage Efficiency\| Dam ${ }^{(a)}$ & $0.883(\widehat{\mathrm{SE}}=0.006)$ & $0.857(\widehat{\mathrm{SE}}=0.010)^{(\mathrm{b})}$ & $0.908(\widehat{\mathrm{SE}}=0.008)^{(\mathrm{b})}$ \\
\hline Spill Passage Efficiency $\|$ Dam $^{(a)}$ & $0.776(\widehat{\mathrm{SE}}=0.008)$ & $0.741(\widehat{\mathrm{SE}}=0.012)^{(\mathrm{b})}$ & $0.810(\widehat{\mathrm{SE}}=0.011)^{(\mathrm{b})}$ \\
\hline
\end{tabular}

(a) If dam route is included, proportions will not add to 1 .

(b) Significantly different. 


\subsection{Discussion}

This section briefly discusses the reasonableness of primary survival model assumptions, the historical context for estimates, and the statistical performance of the double detection array and spilltreatment results.

\subsection{Reasonableness of Model Assumptions}

The survival study at JDA was a precursor to a full-scale application of the virtual/paired-release model (Skalski et al. 2010) in 2011, but the single-release survival model used in this study has some of the same assumptions as the virtual/paired-release survival model.

Overall, the primary assumptions of the single-release survival model used for this study were reasonable. Analyses found no tagger effects that might confound estimation of dam passage survival. Handling and tagging mortalities during the study were minimal and no tags were shed during the $24 \mathrm{~h}$ post-surgery holding period. Travel times were sufficiently short, relative to tag life, to adequately adjust the release-recapture data for tag failure, if needed. However, tag life for the 2010 summer study was adequate to ensure nearly all $\mathrm{CH} 0$ passed the tertiary array at $\mathrm{BON}$ before tag-life failure was problematic. Therefore, a tag-life correction was not applied to survival estimates in summer. In all cases, the probability that an acoustic tag was active at a downstream detection location was $>0.99$. The distribution of fish lengths for juvenile salmonids used in the tagging study were slightly offset from ROR CH0 sampled at the JDA Smolt Monitoring Facility by the Fish Passage Center. The primary reason was the lower limit size restriction of fish $<95 \mathrm{~mm}$ in length. This size limit has been implemented because the tag/fish-weight ratio (tag burden) is a confounding migratory factor, particularly in smaller fish; it can impede swim performance and increase predation events (Adams et al. 1998).

\subsection{Historical Context}

Historically, telemetry studies have been used at JDA to estimate survival rates for CH0. Until 2006, radio telemetry (RT) had been the primary mode for obtaining survival estimates. Although similarities exist between RT and JSATS study designs, the mechanisms for obtaining and processing raw acoustic and radio signals differ greatly. When comparing RT survival estimates to JSATS survival estimates, one must consider differences not only in study design (release locations, reaches defined, location of detection arrays, etc.), but in the manner in which fish were tagged and released (RT - antennae external protrusion, JSATS - internal tag, etc.).

More comparable JSATS survival studies have been conducted at JDA in 2006 (Ploskey et al. 2007) and more recently in 2008 and 2009 (Weiland et al. 2009, 2011). In 2008 and 2009, fish were released near Arlington, Oregon (rkm 390), and regrouped on the JDA forebay entrance array to create virtual releases for estimating single- and paired-release dam passage survival rates in 2009 and 2008, respectively. Tag-life-corrected survival rates from $2 \mathrm{rkm}$ upstream of JDA to the TDA forebay are shown in Table 4.1 with results from the JDA summer 2010 survival study for comparison. Dam passage survival estimates for $\mathrm{CH} 0$ from 2008-2010 range from $0.839 \pm 0.014$ (2009) to $0.959 \pm 0.011$ (2008). 
Table 4.1. Single-Release Survival Estimates of CH0 at JDA from 2008 to 2010

\begin{tabular}{cccc}
\hline Year & Survival & $30 \%$ Spill & $40 \%$ Spill \\
\hline 2008 & $0.959 \pm 0.011$ & - & - \\
2009 & $0.839 \pm 0.014$ & $0.842 \pm 0.040$ & $0.840 \pm 0.051$ \\
2010 & $0.908 \pm 0.006$ & $0.919 \pm 0.008$ & $0.914 \pm 0.008$ \\
\hline
\end{tabular}

Numerous studies using acoustic telemetry (AT), RT, and hydroacoustic (HA) technologies, have estimated FPE and SPE (BiOp performance criteria) at JDA since 1983. Summarized in Table 4.2 are estimates obtained since the year 2002 to include AT, RT, and HA for FPE and SPE.

Table 4.2. Estimates of Spill Passage Efficiency and Fish Passage Efficiency for $\mathrm{CHO}$ from Current and Previous Radio Telemetry (RT), Acoustic Telemetry (AT), and Hydroacoustic (HA) Studies at JDA from 2002 to 2010. TSWs were installed in 2008 and 2010.

\begin{tabular}{ccccc}
\hline Year & Study Type & SPE & FPE & References \\
\hline \multirow{2}{*}{2002} & RT $-(30 / 30 \%)$ & $57.8 \%$ & $70.4 \%$ & Beeman et al. (2007) \\
& HA - (30/30\%) & $60.9 \%$ & $88.0 \%$ & Moursund et al. (2003) \\
2003 & RT - (30/30\%) & $61.7 \%$ & $74.8 \%$ & Hansel et al. (2004) \\
\multirow{2}{*}{2008} & AT Combined & $68.60 \pm 2.4 \%$ & $83.30 \pm 1.9 \%$ & \\
& AT 30\% & $65.71 \pm 3.8 \%$ & $82.03 \pm 2.9 \%$ & Weiland et al. (2009) \\
& AT 40\% & $71.08 \pm 3.8 \%$ & $84.43 \pm 2.9 \%$ & \\
\multirow{2}{*}{$2009^{(\text {a) }}$} & AT Combined & $73.20 \pm 1.6 \%$ & $84.51 \pm 1.3 \%$ & \\
& AT 30\% & $69.68 \pm 2.9 \%$ & $83.07 \pm 2.2 \%$ & Weiland et al. (2011) \\
& AT 40\% & $76.04 \pm 2.4 \%$ & $85.61 \pm 2.2 \%$ & \\
\multirow{2}{*}{2010} & AT Combined & $77.6 \pm 0.8 \%$ & $88.3 \pm 0.6 \%$ & \\
& AT 30\% & $74.1 \pm 1.2 \%{ }^{(b)}$ & $85.7 \pm 1.0 \%$ & Current Study \\
& AT 40\% & $81.0 \pm 1.1 \%{ }^{(\mathrm{b})}$ & $90.8 \pm 0.8 \%{ }^{(\mathrm{b})}$ & \\
\hline
\end{tabular}

(a) TSWs were not operated during the summer season 2009.

(b) Significantly different.

SPE has ranged widely since 2002 at JDA; the lowest reported comparable SPE was the 2002 study year in which RT was the telemetry system used with spill treatments of $30 \%$ and $30 \%$ (day/night) and with an observed SPE of 57.8\%. Concurrently in 2002, a HA study estimated a SPE of $60.9 \%$ with the same spill treatments. However, in recent years (2008-2010) SPE has ranged from $\sim 66 \%$ to $\sim 81 \%$ depending on spill treatment levels and using AT, or in this case JSATS. For the current study, SPE ranged from $74.1 \%$ (30\% spill) to $81.0 \%$ (40\% spill).

From 2008 to 2010 and using AT, FPE at JDA has ranged from $\sim 82 \%$ to $\sim 91 \%$ depending on spill treatment levels. These estimates are higher than previous year estimates by RT in 2002 and 2003 (70.4\% and $74.8 \%$, respectively). HA estimates in 2002 were more comparable to the current study year with a FPE of $88 \%$ with $30 \%$ spill. 


\subsection{Statistical Performance}

The single-release survival study at JDA in 2010 was a precursor to a full-scale application of the virtual/paired-release study design planned for the dam in 2011. The double array at each dam face provided a combined detection probability of $100 \%$, indicating that dam-face deployments are ready for the full BiOp study in 2011. 


\subsection{References}

Adams NS, DW Rondorf, SD Evans, and JE Kelly. 1998. "Effects of Surgically and Gastrically Implanted Radio Transmitters on Swimming Performance and Predator Avoidance of Juvenile Chinook Salmon (Oncorhynchus tshawytscha)." Canadian Journal of Fisheries and Aquatic Sciences 55(4):781-787.

Beeman JW, SD Fielding, AC Braatz, TS Wilkerson, AC Pope, CE Walker, JM Hardiman, RW Perry, and TD Counihan. 2007. Survival and Migration Behavior of Juvenile Salmonids at Lower Granite Dam, 2006. Final Report of Research prepared by the U.S. Geological Survey, Cook, Washington, for the U.S. Army Corps of Engineers, Walla Walla District, Contract W68SBV60378208, Walla Walla, Washington.

Burnham KP, DR Anderson, GC White, C Brownie, and KH Pollock. 1987. Design and Analysis Methods for Fish Survival Experiments Based on Release-Recapture. Monograph 5, American Fisheries Society, Bethesda, Maryland.

CBR (Columbia Basin Research). 2012a. "Active Tag-Life-Adjusted Survival (ATLAS)," CBR Parameter Estimation Software. School of Aquatic \& Fishery Sciences, University of Washington, Seattle, Washington. Available at http://www.cbr.washington.edu/paramest/atlas/.

CBR (Columbia Basin Research). 2012b. "User Specified Estimation Routine (USER)," CBR Parameter Estimation Software. School of Aquatic \& Fishery Sciences, University of Washington, Seattle, Washington. Available at http://www.cbr.washington.edu/paramest/user/.

Hansel HC, JW Beeman, BJ Hausmann, SD Juhnke, PV Haner, and JL Phelps. 2004. Estimates of Fish, Spill, and Juvenile Fish Bypass Passage Efficiencies of Radio-Tagged Juvenile Salmonids Relative to Spring and Summer Spill Treatments at John Day Dam in 2003. Final Report of Research prepared by the U.S. Geological Survey, Cook, Washington, for the U.S. Army Corps of Engineers, Portland, Oregon.

Li T and JJ Anderson. 2009. "The vitality model: A way to understand population survival and demographic heterogeneity." Theoretical Population Biology 76:118-131.

Martinson R, G Kovalchuk, and D Ballinger. 2006. Monitoring of Downstream Salmon and Steelhead at Federal Hydroelectric Facilities. 2005-2006 Annual Report, Project No. 198712700, BPA Report DOE/BP-00022085-2, Bonneville Power Administration, Portland, Oregon.

Moursund RA, KD Ham, and PS Titzler. 2003. Hydroacoustic Evaluation of Downstream Fish Passage at John Day Dam in 2002. PNWD-3236, prepared for U.S. Army Corps of Engineers District, Portland, Oregon, by Pacific Northwest National Laboratory, Richland, Washington.

National Oceanic and Atmospheric Administration (NOAA) Fisheries. 2008. Biological OpinionConsultation on Remand for Operation of the Federal Columbia River Power System, 11 Bureau of Reclamation Projects in the Columbia Basin and ESA Section 10(a)(1)(A) Permit for Juvenile Fish Transportation Program. National Marine Fisheries Service (NOAA Fisheries) - Northwest Region, Seattle, Washington. 
Ploskey GR, MA Weiland, JS Hughes, SA Zimmerman, RE Durham, ES Fischer, J Kim, RL Townsend, JR Skalski, and RL McComas. 2007. Acoustic Telemetry Studies of Juvenile Chinook Salmon Survival at the Lower Columbia Projects in 2006. PNNL-16560, Pacific Northwest National Laboratory, Richland, Washington.

Seber GAF. 1982. The Estimation of Animal Abundance. MacMillan, New York.

Skalski JR, RL Townsend, TW Steig, and S Hemstrom. 2010. "Comparison of two alternative approaches for estimating dam passage survival using acoustic-tagged sockeye salmon smolts." North American Journal of Fisheries Management 30:831-839.

Townsend RL, JR Skalski, P Dillingham, and TW Steig. 2006. "Correcting bias in survival estimation resulting from tag failure in acoustic and radio telemetry studies." Journal of Agricultural Biology and Environmental Statistics 11(2):183-196.

Weiland MA, GR Ploskey, JS Hughes, Z Deng, T Fu, TJ Monter, GE Johnson, F Khan, MC Wilberding, AW Cushing, SA Zimmerman, DM Faber, RE Durham, RL Townsend, JR Skalski, J Kim, ES Fischer, and MM Meyer. 2009. Acoustic Telemetry Evaluation of Juvenile Salmonid Passage and Survival at John Day Dam with Emphasis on the Prototype Surface Flow Outlet, 2008. PNNL-18890, Pacific Northwest National Laboratory, Richland, Washington.

Weiland MA, GR Ploskey, JS Hughes, Z Deng, T Fu, JA Kim, GE Johnson, ES Fischer, F Khan, SA Zimmerman, DM Faber, KM Carter, JW Boyd, RL Townsend, JR Skalski, TJ Monter, AW Cushing, MC Wilberding, and MM Meyer. 2011. Acoustic Telemetry Evaluation of Juvenile Salmonid Passage and Survival Proportions at John Day Dam, 2009. PNNL-20766, Pacific Northwest National Laboratory, Richland, Washington. 


\section{Appendix}

\section{Capture-History Data}




\section{Appendix}

\section{Capture-History Data}

Table A.1. Capture Histories at the John Day Dam Dam-Face Array ( $\mathrm{V}_{2}$; CR349), TDA Dam-Face Array (CR309), the Hood River Autonomous Node Array (CR275), and the BON Dam-Face Array (CR234) for Release Group $V_{2}$ for Subyearling Chinook Salmon Used in Estimating Dam Passage Survival. A "1" denotes detection, "0" denotes non-detection, and "2" denotes detection and censoring due to removal.

\begin{tabular}{|c|c|}
\hline $\begin{array}{l}\text { Capture } \\
\text { History } \\
\end{array}$ & $\begin{array}{c}\text { Subyearling } \\
\text { Chinook Salmon } \\
\left(\mathrm{V}_{2}\right) \\
\end{array}$ \\
\hline $1112:$ & 31 \\
\hline 1111 : & 2028 \\
\hline 0111 : & 3 \\
\hline 1011 : & 0 \\
\hline 0011 : & 0 \\
\hline $1101:$ & 1 \\
\hline $0101:$ & 0 \\
\hline $1001:$ & 1 \\
\hline 0001 : & 0 \\
\hline $1120:$ & 0 \\
\hline 0120 : & 0 \\
\hline 102 0: & 0 \\
\hline 002 0: & 0 \\
\hline 1110 : & 163 \\
\hline 0110 : & 0 \\
\hline 1010 : & 0 \\
\hline 0010 : & 0 \\
\hline 1200 : & 0 \\
\hline 020 0: & 0 \\
\hline 1100 : & 191 \\
\hline 0100 : & 0 \\
\hline 2000 : & 1 \\
\hline 1000 : & 245 \\
\hline 0000 : & 185 \\
\hline
\end{tabular}


Table A.2. Capture Histories for 30\% Spill Treatments at the John Day Dam Dam-Face Array ( $\mathrm{V}_{2}$; CR349), TDA Dam-Face Array (CR309), the Hood River Autonomous Node Array (CR275), and the BON Dam-Face Array (CR234) for Release Group $V_{2}$ for Subyearling Chinook Salmon Used in Estimating Dam Passage Survival. A "1" denotes detection, "0" denotes non-detection, and " 2 " denotes detection and censoring due to removal.

\begin{tabular}{|c|c|}
\hline $\begin{array}{l}\text { Capture } \\
\text { History }\end{array}$ & $\begin{array}{l}\text { Subyearling } \\
\text { Chinook } \\
\text { Salmon }\left(V_{2}\right) \\
\end{array}$ \\
\hline $1112:$ & 11 \\
\hline $1111:$ & 1000 \\
\hline 0111 : & 0 \\
\hline 1011 : & 0 \\
\hline 0011 : & 0 \\
\hline $1101:$ & 1 \\
\hline $0101:$ & 0 \\
\hline 1001 : & 1 \\
\hline $\begin{array}{llll:}0 & 0 & 0 & 1:\end{array}$ & 0 \\
\hline $1120:$ & 0 \\
\hline 0120 : & 0 \\
\hline 1020 : & 0 \\
\hline $\begin{array}{llll}0 & 0 & 20 \text { : }\end{array}$ & 0 \\
\hline 1110 : & 73 \\
\hline 010 : & 0 \\
\hline 1010 : & 0 \\
\hline 0010 : & 0 \\
\hline 1200 : & 0 \\
\hline 0200 : & 0 \\
\hline $1100:$ & 100 \\
\hline 0100 : & 0 \\
\hline 2000 : & 1 \\
\hline 1000 : & 117 \\
\hline $\begin{array}{llll:}0 & 0 & 0 & 0:\end{array}$ & - \\
\hline
\end{tabular}


Table A.3. Capture Histories for 40\% Spill Treatments at the John Day Dam Dam-Face Array ( $\mathrm{V}_{2}$; CR349), TDA Dam-Face Array (CR309), the Hood River Autonomous Node Array (CR275), and the BON Dam-Face Array (CR234) for Release Group $V_{2}$ for Subyearling Chinook Salmon Used in Estimating Dam Passage Survival. A "1" denotes detection, "0" denotes non-detection, and " 2 " denotes detection and censoring due to removal.

\begin{tabular}{|c|c|}
\hline $\begin{array}{l}\text { Capture } \\
\text { History }\end{array}$ & $\begin{array}{c}\text { Subyearling } \\
\text { Chinook } \\
\text { Salmon } \\
\left(\mathrm{V}_{2}\right) \\
\end{array}$ \\
\hline $1112:$ & 20 \\
\hline $1111:$ & 1028 \\
\hline 0111 : & 0 \\
\hline 1011 : & 0 \\
\hline 0011 : & 0 \\
\hline $1101:$ & 0 \\
\hline $0101:$ & 0 \\
\hline 1001 : & 0 \\
\hline 0001 : & 0 \\
\hline 1120 : & 0 \\
\hline 0120 : & 0 \\
\hline $1020:$ & 0 \\
\hline 0020 : & 0 \\
\hline $1110:$ & 90 \\
\hline $01110:$ & 0 \\
\hline 1010 : & 0 \\
\hline 0010 : & 0 \\
\hline $1200:$ & 0 \\
\hline 0200 : & 0 \\
\hline $1100:$ & 91 \\
\hline $0100:$ & 0 \\
\hline 2000 : & 0 \\
\hline 1000 : & 128 \\
\hline $\begin{array}{llll:}0 & 0 & 0 & 0:\end{array}$ & - \\
\hline
\end{tabular}


Table A.4. Capture Histories at the John Day Dam Forebay Array $\left(\mathrm{V}_{1}\right.$; CR351), TDA Dam-Face Array (CR309), the Hood River Autonomous Node Array (CR275), and the BON Dam-Face Array (CR234) for Release Group $V_{1}$ for Subyearling Chinook Salmon Used in Estimating Forebay Entrance Array to The Dalles Dam Survival. A "1" denotes detection, "0" denotes nondetection, and " 2 " denotes detection and censoring due to removal.

\begin{tabular}{|c|c|}
\hline $\begin{array}{l}\text { Capture } \\
\text { History }\end{array}$ & $\begin{array}{l}\text { Subyearling } \\
\text { Chinook } \\
\text { Salmon }\left(V_{1}\right) \\
\end{array}$ \\
\hline $1112:$ & 31 \\
\hline 1111 : & 2031 \\
\hline 0111 : & 0 \\
\hline 1011 : & 0 \\
\hline 0011 : & 0 \\
\hline $1101:$ & 1 \\
\hline 0101 : & 0 \\
\hline 1001 : & 1 \\
\hline 0001 : & 0 \\
\hline 1120 : & 0 \\
\hline 0120 : & 0 \\
\hline 1020 : & 0 \\
\hline 0020 : & 0 \\
\hline $1110:$ & 163 \\
\hline 01110 : & 0 \\
\hline 1010 : & 0 \\
\hline 0010 : & 0 \\
\hline 1200 : & 0 \\
\hline 0200 : & 0 \\
\hline 1100 : & 191 \\
\hline 0100 : & 0 \\
\hline 2000 : & 1 \\
\hline 1000 : & 256 \\
\hline $\begin{array}{llll:}0 & 0 & 0 & 0:\end{array}$ & 174 \\
\hline
\end{tabular}


Table A.5. Capture Histories 30\% Spill Treatments at the John Day Dam Forebay Entrance Array $\left(\mathrm{V}_{1}\right.$; CR351), TDA Dam-Face Array (CR309), the Hood River Autonomous Node Array (CR275), and the BON Dam-Face Array (CR234) for Release Group $V_{1}$ for Subyearling Chinook Salmon Used in Estimating Forebay Entrance Array to The Dalles Dam Survival. A "1" denotes detection, " 0 " denotes non-detection, and " 2 " denotes detection and censoring due to removal.

\begin{tabular}{|c|c|}
\hline $\begin{array}{l}\text { Capture } \\
\text { History } \\
\end{array}$ & $\begin{array}{c}\text { Subyearling } \\
\text { Chinook } \\
\text { Salmon }\left(\mathrm{V}_{1}\right) \\
\end{array}$ \\
\hline $1112:$ & 11 \\
\hline 1111 : & 1000 \\
\hline 0111 : & 0 \\
\hline 1011 : & 0 \\
\hline 0011 : & 0 \\
\hline $1101:$ & 1 \\
\hline 010 1: & 0 \\
\hline $1001:$ & 1 \\
\hline 000 1: & 0 \\
\hline 1120 : & 0 \\
\hline 0120 : & 0 \\
\hline 102 0: & 0 \\
\hline 002 0: & 0 \\
\hline 1110 : & 73 \\
\hline 0110 : & 0 \\
\hline 1010 : & 0 \\
\hline 00010 : & 0 \\
\hline 1200 : & 0 \\
\hline 0200 : & 0 \\
\hline $1100:$ & 100 \\
\hline 0100 : & 0 \\
\hline 2000 : & 1 \\
\hline 1000 : & 116 \\
\hline $\begin{array}{llll:}0 & 0 & 0 & 0:\end{array}$ & - \\
\hline
\end{tabular}


Table A.6. Capture Histories for 40\% Spill Treatments Level at John Day Dam Forebay Entrance Array $\left(\mathrm{V}_{1}\right.$; CR351), TDA Dam-Face Array (CR309), the Hood River Autonomous Node Array (CR275), and the BON Dam-Face Array (CR234) for Release Group $\mathrm{V}_{1}$ for Subyearling Chinook Salmon Used in Estimating Forebay Entrance Array to The Dalles Dam Survival. A " 1 " denotes detection, " 0 " denotes non-detection, and " 2 " denotes detection and censoring due to removal.

\begin{tabular}{|c|c|}
\hline $\begin{array}{l}\text { Capture } \\
\text { History }\end{array}$ & $\begin{array}{c}\text { Subyearling } \\
\text { Chinook } \\
\text { Salmon }\left(\mathrm{V}_{1}\right) \\
\end{array}$ \\
\hline $1112:$ & 20 \\
\hline $1111:$ & 1028 \\
\hline 0111 : & 0 \\
\hline 1011 : & 0 \\
\hline 0011 : & 0 \\
\hline $1101:$ & 0 \\
\hline $0101:$ & 0 \\
\hline $1001:$ & 0 \\
\hline $\begin{array}{llll:}0 & 0 & 0 & 1:\end{array}$ & 0 \\
\hline 1120 : & 0 \\
\hline 0120 : & 0 \\
\hline 1020 : & 0 \\
\hline 0020 : & 0 \\
\hline 1110 : & 90 \\
\hline 01110 : & 0 \\
\hline 1010 : & 0 \\
\hline 0010 : & 0 \\
\hline 1200 : & 0 \\
\hline 0200 : & 0 \\
\hline 1100 : & 91 \\
\hline 0100 : & 0 \\
\hline 2000 : & 0 \\
\hline 1000 : & 128 \\
\hline $\begin{array}{llll:}0 & 0 & 0 & 0:\end{array}$ & - \\
\hline
\end{tabular}




\section{Distribution}

No. of

Copies

\section{External Distribution}

1 Brad Eppard

USACE Portland District

P.O. Box 2946

Portland, OR 97204

1 Mike Langeslay

USACE Portland District

P.O. Box 2946

Portland, OR 97204.

1 John Skalski

University of Washington

1325 4th Avenue

Seattle, WA 98101
No. of

\section{Copies}

\section{Local Distribution}

7 Pacific Northwest National Laboratory

Tom Carlson $\quad$ BPO

Zhiqun Deng $\quad \mathrm{RCH}$

James Hughes $\quad \mathrm{RCH}$

Gene Ploskey NBON

Steve Schlahta $\mathrm{RCH}$

Mark Weiland NBON

Christa Woodley MSL 


\section{ivi:}

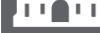

US Army Corps

of Engineers

Prepared for the U.S. Army Corps of Engineers, Portland District, under a Government Order with the U.S. Department of Energy Contract DE-AC05-76RL01830

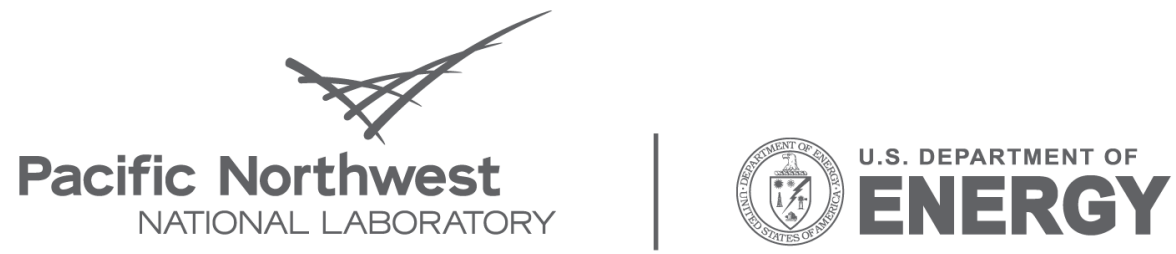

Proudly Operated by Battelle Since 1965

902 Battelle Boulevard

P.O. Box 999

Richland, WA 99352

1-888-375-PNNL (7665)

www.pnl.gov 